\title{
Erosion and Flooding Risks in the Marly Basins of the Eastern Prerif Mountains (Morocco): A Response to Exceptional Climate Events or to Anthropogenic Pressure
}

\author{
Riesgos de Erosión e Inundaciones en las Cuencas Margosas de las Montañas Pre- \\ rif Orientales (Marruecos): Una Respuesta a Eventos Climáticos Excepcionales \\ o/a la Presión Antropogénica
}

\author{
Abdellatif Tribak \\ abdellatif.tribak@usmba.ac.ma @ https://orcid.org/0000-0002-1564-5886 \\ School of Geography. Sidi Mohamed Ben Abdellah University. \\ FLSH -SAIS. BP: 59, Route Immouzer. CP 30000 Fès Maroc.
}

\section{INFO ARTÍCULO}

Recibido: 07-04-2020

Revisado: $15-06-2020$

Aceptado: 17-06-2020

\section{KEYWORDS}

Rif Mountains

Rainfall severity

Anthropogenic Actions

Erosion

Floods

\begin{abstract}
The Eastern Rif Mountains are frequently subject to exceptional rainfall events, whose consequences are sometimes disastrous. The impact of these phenomena on environments is more important as the majorities of slopes are bare and subject to strong human influence. The protective natural forests of the slopes are almost destroyed; they currently cover only a few peaks of mountains in the region. They represent $1.84 \%$ of the total area of wadi Tleta sub-basin and only $1.32 \%$ of the Tarmast wadi sub-basin. However, croplands, occupying respectively $60 \%$ and $34 \%$ in the two sub-basins, extend even on the steepest slopes. Similarly, the accelerated and uncontrolled human occupation of the urban peripheries, located downstream of the basins, amplifies the vulnerability of these environments to the hydrological hazards, that threaten several sites surrounding the agglomeration of Taza.

Thus, the whole region is subject to different degradation processes. Hydric erosion affects the majority of the slopes; it causes excessive sediment production that may exceed $60 \mathrm{t} \mathrm{ha}^{-1}$ year $^{-1}$ in some sub-basins. Similarly, flood disasters are quite common in the region. The flood of 20/9/2000 is a reference, with a volume estimated at 4 million $\mathrm{m}^{3}$ (DRH-Sebou 2000). Human and material damage was enormous in the rural centers and in the northern outlying districts of Taza. This contribution aims to present and analyze the combined impacts of the extreme rains and the actions of the human societies on the dynamics of the prerifain environment and its adjoining spaces.
\end{abstract}

\section{RESUMEN}

Las montañas del este del Rif están frecuentemente sujetas a eventos de lluvia excepcionales, cuyas consecuencias son a veces desastrosas. El impacto de estos fenómenos en los entornos es muy importante ya que la mayoría de las pendientes son desnudas y están sujetas a una fuerte influencia humana. Los bosques naturales protectores de las laderas están casi destruidos; actualmente cubren solo unos pocos picos de montañas en la región. Representan el $1.84 \%$ del área total de la subcuenca del wadi Tleta y solo el $1.32 \%$ de la subcuenca del wadi Tarmast. Sin embargo, las tierras de cultivo, que ocupan respectivamente el $60 \%$ y el $34 \%$ en las dos subcuencas, se extienden incluso en las pendientes más empinadas. Del mismo modo, la ocupación humana acelerada e incontrolada de las periferias urbanas, ubicadas aguas abajo de las cuencas, amplifica la vulnerabilidad de estos entornos a los riesgos hidrológicos, que amenazan varios sitios que rodean la aglomeración de Taza. Por lo tanto, toda la región está sujeta a diferentes procesos de degradación. La erosión hídrica afecta a la mayoría de las pendientes; causa una producción excesiva de sedimentos que puede superar las $60 \mathrm{t} \mathrm{ha}^{-1} \mathrm{año}^{-1}$ en algunas subcuencas; del mismo modo, los desastres por inundación son bastante comunes en la región. 


\begin{abstract}
La inundación del 20/9/2000 es una referencia, con un volumen estimado en 4 millones de $\mathrm{m}^{3}$ (DRH-Sebou 2000). El daño humano y material fue enorme en los centros rurales y en los distritos periféricos del norte de Taza. Esta contribución tiene como objetivo presentar y analizar los impactos combinados de las lluvias extremas y las acciones de las sociedades humanas sobre la dinámica de estos ambientes de montaña y sus espacios adyacentes.
\end{abstract}

\title{
1. INTRODUCTION
}

It is certain that interest in natural risks continues to grow on a planetary scale. Indeed, with the climatic variability, well perceptible during the last decades, the world has known incessantly tragic events, having unfortunate consequences. This problem of natural risks is now located at the crossroads of several fields of scientific research; it concerns actors of various natures. Since 1990, the contribution of scientists in the animation of the subject is more and more abundant and important; with a growing influence during this period of the social sciences. Indeed, several methods have been adopted with the aim of reintroducing social and political factors in the analysis of natural disasters, by trying to go beyond the dominant approaches of the earth sciences, focused only on natural phenomena. Hydrous erosion, in all its forms and processes, as well as floods, represent natural calamities that are widespread on the surface of the globe. In relation with recent climatic variability and multiple anthropogenic pressures, these phenomena are more and more frequent and the damage they generate is constantly increasing.

By its geographical situation in the Mediterranean basin, Morocco is marked by a strong rainfall irregularity which generates very violent hydrological behaviors, particularly in the catchments characterized by topographical, geological and anthropic factors which accelerate the irregularity of the extreme forms of flow. Thus, despite the global warming and recurring droughts that have characterized the country since the 1980s, exceptional rainfall events are quite frequent in several regions of the country (Ourika 1994, El Hajeb 1997, El Jadida 1996, Taza 1995, 1997, 2000, 2002 and 2010, Mohamedia 2002, Demnat 2005, Nador 2008 and all the North of Morocco in 2009 and 2010, etc). In each episode, huge quantities of water are released in a matter of days or few hours, with very high instantaneous intensities. The succession of such events constitutes a permanent risk that threatens several northern and sometimes some southern provinces (Agadir 2009-2010-2018). Several Moroccan cities have been painfully hit by catastrophic floods during these last decades. The recent case concerns the city of El Jebha, located on the Mediterranean coast in northern Morocco; it suffered a real disaster following floods and catastrophic landslides caused by torrential rain during the afternoon of March 24th, 2020. The frequencies of these phenomena and their serious consequences constitute a crucial problem for sustainable development and regional planning in Morocco. They reflect a high degree of vulnerability which often show human involvement and responsibility for the catastrophic events linked to erosion and flood crises.

The Prerif Mountains, carved mainly in tertiary marly rocks and almost completely denuded, are increasingly concerned by such rainy episodes that cause extreme forms of flow leading to intense erosion on the slopes and disastrous floods downstream of the basins. This situation is reinforced by a strong human pressure on the slopes and by an increasingly aggravated occupation of the sites at risk, due to a rapid and uncontrolled urbanization of the peripheral zones of the agglomerations.

The concerned area is part of the eastern prerif at the north of Taza, occupying a downstream position within the watersheds of wadi Lahdar, and wadi Larbâa (figure1). It is characterized by a rugged topography of hills and low mountains that offer a pattern of irregular slopes, related to the structural feature and the importance of dissection and quaternary inheritances. The geological context shows a clear predominance of tertiary marly rocks in a structure marked by thrust sheets (Leblanc, 1979). Marly series dated from Cretaceous and especially from the end of the Tertiary, occupy almost all the region. They are partly surmounted by sandstone formations that particularly arm the allochthonous units. The region is evolving in a semi-arid mediterranean climate, associated with a strong irregularity of annual rainfall and seasonal contrasts. Annual averages are $681 \mathrm{~mm}$ for the Had Msila station (1970-2016) and $600 \mathrm{~mm}$ for the Taza station (1970 -2016). 


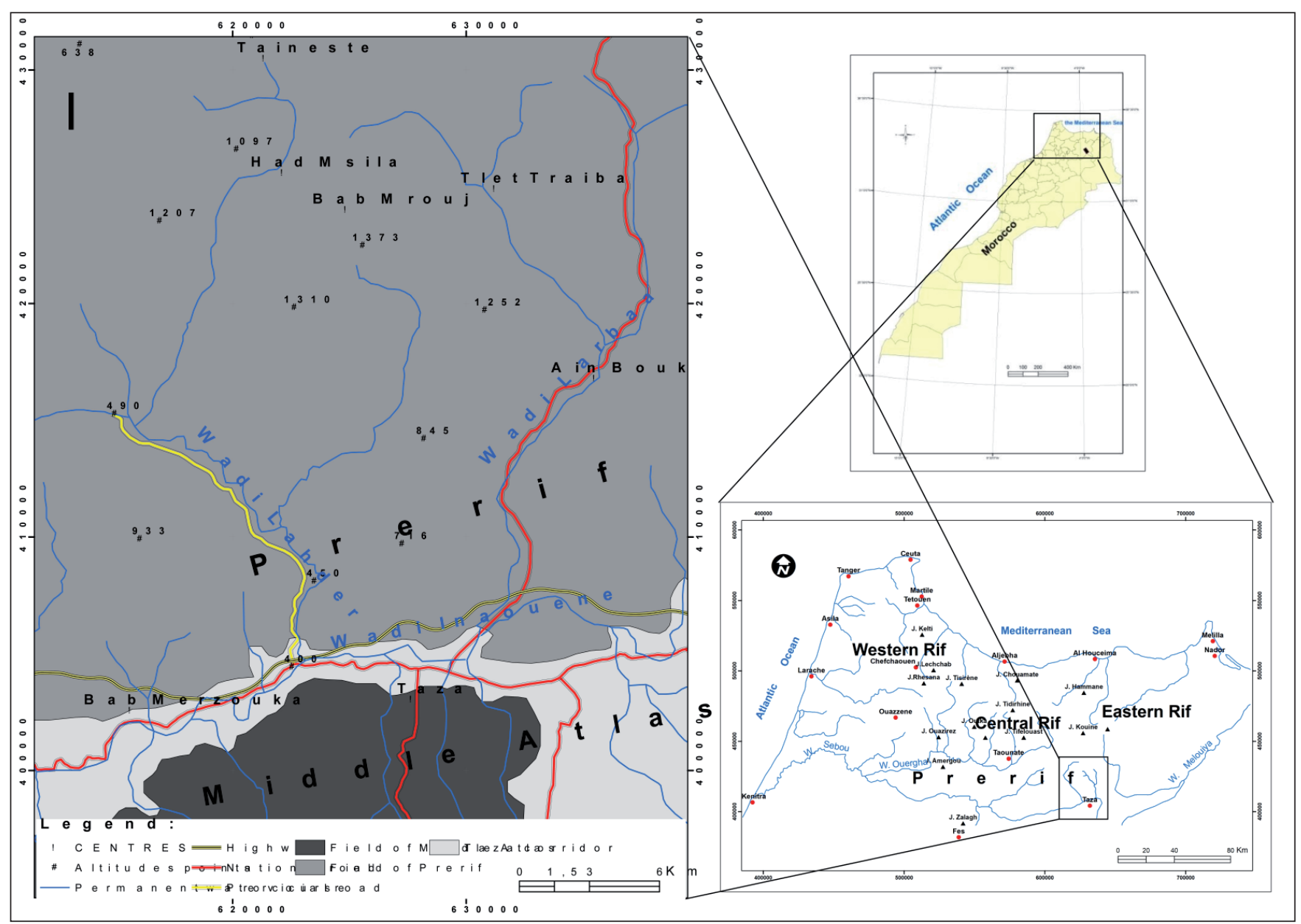

Figure 1. Location of the oriental Prerif zone.

During this period the Taza station recorded maximum annual rainfall reaching $1125 \mathrm{~mm}$ in 2009/2010 and a minimum of $275 \mathrm{~mm}$ in 1994/1995. Similarly, the Had Msila station recorded a maximum value of $1411 \mathrm{~mm}$ in the year 2009/2010 and a minimum value of $280 \mathrm{~mm}$ during the year 1994/1995.

The region is an old demographic home where the settlement is very old (Tribak, 2000). Human densities remain impressive; despite the migratory movements in the last decades, they still exceed the $60 \mathrm{~h} /$ $\mathrm{km}^{2}$ threshold in all municipalities in the Taineste district (HCP-RGPH, 2004). This human pressure, to which different land-use patterns are linked, explains largely the great variability of environmental degradation phenomena. The overexploitation of cleared land, fueled by a rapidly growing population, explains the extension of crops to areas with steep slopes, resulting in the acceleration of runoff coefficients and erosion processes in this fragile environment.

In this rifain area, soil erosion is a crucial problem that threatens the economy of the region and destabilizes the lives of local population, already precarious. It is accelerated following to the clearing of forests that protected sensitive soils. The intense erosion processes on the marly slopes as well as the extremely rapid evolution of the gullies, degrades the soil capital and allows evacuating huge quantities of sediments annually to the main collectors, threatening the road and hydraulic infrastructures, and residential districts. Similarly, the large runoff coefficients, caused on the bare marly slopes during extreme rains, are occasionally favorable to catastrophic floods, which painfully affect the outlying districts of Taza which have developed, in an uncontrolled manner, in the confluence zone of the entire hydrographic network draining the watershed of the wadi Larbâ, and where takes refuge a dense population often in precarious situations.

This contribution synthesizes the research work done in the region, during the last two decades, on the phenomena of runoff and erosion. It aims to present and analyze the combined impacts of the extreme rainfall events and the actions of the human societies on the dynamics of the prerifan environment and its 
adjoining spaces. The aim is also to deepen the understanding of the functioning of this environment and to contribute to the various debates and projects concerning regional planning and the fight against disasters caused by natural hazards.

The following hypotheses should therefore be emphasized:

- Multiple human actions accentuate the intrinsic fragility of this environment and consequently, accelerate the irregularity of extreme flows and the aggressiveness of the dynamic processes.

- The uncontrolled human occupations in the peripheral areas of the cities create new vulnerabilities and amplify the disasters caused by extreme floods.

\section{MATERIALS AND METHODS}

The climate study approach relies on the use of meteorological data relating to a series of rainfall measurements in both Taza and Had Msila station for the period (1970 - 2016). Other climatic data were taken from bibliographical references of previous studies (Tribak, 2000; Tribak, 2002; Tribak, 2007; Tribak, El Garouani \& Abahrour, 2012; DRH Sebou, 2000; Akdim, Laaouane, Taous \& Obda, 2003; Taous et al. 2010; Abahrour, 2009; Abahrour, 2015). Similarly, time situations were analyzed by referring to the weather maps provided by the German site www.Wetter3.de, which allowed us to follow the temporal evolution of the disturbances during the rainy events. The choice of synoptic situations is made according to the availability of rainfall data and their amount, then to the damage caused during exceptional rainy periods. The analysis concerns the situations at $500 \mathrm{hPa}$ geopotential height compared, in the case of convective episodes, with mapping at a lower geopotential level of $850 \mathrm{hPa}$. The exploitation of the collected data aims to appreciate in more detail the extreme rainfall parameters which constitute determining elements in the acceleration of the erosion and the genesis of the flooding phenomena.

The historical dimension of this study was approached on the basis of bibliographic research. Administrative records and reports from the Urban Agency, the Ministry of Housing and the Office of the High Commissioner for Planning (HCP) have been helpful in supporting our results from the field. Such are the cases for the reports of the Taza province and Urban Agency, and the hydraulic agency of the sebou basin for the year 2000.

This work has been supplemented by more spatially and thematically targeted field research. Surveys and fieldwork allowed us to verify and complete the photo-interpretation, concerning details of the natural and anthropogenic causes of erosion and flooding phenomena. Concerning this research component, it is very important to identify the remains of the sediments and the different traces of floods in the affected zones and to interview the local population. These traces provide rich information on flow dynamics and deposition at the time of submersion. In the same way, the interviews with the population inform us about the history of the past floods and the extent of the damage suffered. It is therefore a question of characterizing and classifying the past floods, identified according to the information collected in the field, because it is rare to have sufficient and reliable data on rainfall amounts and flood flows. Thus, flood events classification can be based on spatial extent, damage, casualties, and, if possible, the height reached by the flood during submersion (Akdim et al., 2003., Taous et al., 2010). The only flood, for which we have reliable data, during the last two decades, is that of 20/9/2000 which we have taken as a reference flood. It is considered to be the most serious level of flood hazard and for which more data are available.

Exploitation of aerial photographs and satellite images, from different missions, allowed us to map, and support field study results concerning land use, erosion patterns, and the extension of the flood zones downstream of the basins. The interpretation of the aerial photos concerned respectively the missions of 1962 (scale - 1/17500) and 1986 (scale -1/20000). The current land use in the area is carried out from the analysis of the image LandSat of October 8th, 2017 (resolution $30 \mathrm{~m}$ ) downloaded from the site https:// earthexplorer.usgs.gov.

The quantification of the hydric erosion in different sub-basins of the region is carried out by the RUSLE model (Renard, Foster, Weesies, McCool \& Yoder, 1997; Bonn, 1998); based on a linear function involving 
the spatial combination of the different parameters contributing to soil erosion (Lewis, Chen \& El Garouani, 2007; El Garouani, Chen, Lewis, Tribak \& Abahrour, 2009; Tribak, El Garouani et al., 2009; Arari, Tribak, Amhani \& El Ommal, 2019). In this approach, we proceeded to a spatialization of hydrous erosion by considering the parameters that influence erosive dynamics in the concerned basins. It relies on the collection, and the spatial analysis of the data concerning the physical constraints, the land use and the geomorphology of the environments. We, therefore, proceeded by extracting the thematic information from the satellite images (Landsat TM 1987, resolution $30 \mathrm{~m}$ and Landsat ETM + /2000 and 2014, resolution $20 \mathrm{~m}$ ), the soil study in the field and at the laboratory, and the exploitation of a digital terrain model (DTM created from digital topographic maps of the region) and the derived data such as declivity and length of slopes. In this work we used ArcGIS 10.1 software for scanning all required information layers and spatial analysis operations (Lewis et al., 2007). In addition; we used the Erdas Imagine software for the treatment of remote sensing imagery for land use mapping (El Garouani et al., 2009; Tribak, Abahrour, El Garouani, Arari \& Amhani, 2017; Arari et al., 2019).

The RUSLE model integrated into the Idrisi software allowed us to evaluate the average annual rate of erosion in some sub-basins of the region, according to the distribution of rainfall aggressiveness, soil erodibility, topography, land use and crop management practices (Lewis et al., 2007; El Garouani et al., 2009; Tribak et al., 2009; Tribak et al., 2017; Abahrour, 2009; Arari et al., 2019). According to this model, the erosion rate $\left(A\right.$ in $t^{~ h a-1}$ year $\left.^{-1}\right)$ is a multiplicative function of rainfall erosivity $(R)$, which is equal to the potential energy, multiplied by the environmental resistance of the erodibility of the soil $(K)$, topographic factor $(S L)$, vegetation cover and cultural practices $(C)$ and anti-erosion practices (P). A = R. K. SL.C.P

The R-value used for the study area was based on the Rango \& Arnoldus formula (1987) and derived using the 1979-2013 climate data of the regional stations. The aggressiveness of the rains is estimated at 65

The $\mathrm{K}$ value was calculated using the Wischmeier nomogram, the soil map of the study area and the infiltration and soil properties of the area, as developed by Tribak 2000, El garouani et al 2009 and Tribak et al. 2009. The $\mathrm{K}$ factor values, located between 0.22 and 0.46 , show a marked fragility of the soils and their susceptibility to erosion

The LS factor is calculated by the GIS Idrisi Andes software. It uses DTM to calculate slope, slope lengths and slope orientation (Lewis et al., 2007; El Garouani et al., 2009).

The value of the $C$ factor used is based on results from similar earlier studies for some Rifan basins (El Garouani et al., 2009; Tribak et al., 2009; Sadiki, Bouhlassa, Aujjar, Faleh, Macaire, 2004; Naimi, Tayaa \& Ouzizi, 2004; El Aroussi et al., 2011), as well as satellite imagery and the field observations. The values assigned to the different modes of land use is between 0.08 and 0.55

The $P$ factor varies from 1 for non-conservation areas to 0.1 for heavily managed land (Roose, 1996). Due to the lack of regional planning in the study area, the value of 1 was assigned to all basins.

After determining all the necessary parameters, the estimation and the mapping of the soil losses are carried out using the RUSLE model integrated into Idrisi Andes software (Lewis et al., 2007; El Garouani et al., 2009; Tribak et al., 2009; Tribak et al., 2017; Abahrour, 2009; Arari et al., 2019).

In addition, the dynamics of infiltration and runoff according to soil surface conditions was tested by using rainfall simulation on micro-plots $\left(1 \mathrm{~m}^{2}\right)$ using a mini-simulator with rainy ramp with simulated rains of 50 $\mathrm{mm}$ and intensities of $80 \mathrm{~mm} / \mathrm{h}$ (Abahrour, 2009; Abahrour, 2015; Sabir, Roose, Ouagga, Bensalah \& Dore, 2007). Before each simulation, the surface condition of the parcels concerned is checked. It is a question of raising the rate of closed surfaces (pellicle and crust of crushing, packed surfaces and pebbles included in the mass of the ground) and of open surfaces (cracks) and covered surfaces (weeds, litter and pebbles) according to the quadrats points method (Roose, 1996; Sabir et al., 2007, Abahrour, 2009; Morsli, Habi, Mazour, Hamoudi \& Halitim 2012). Likewise, the initial humidity was tested on samples taken before and after the simulation in the surface horizons of each plot. The simulation tests are spread over different periods of the agricultural year in order to test the evolution of the surface conditions and the preliminary humidity of the soil in the different seasons. It involved cultivated plots as well as fallow or totally abandoned plots. 


\section{RESULTS AND DISCUSSION}

The aggressive nature of the exceptional rains and their pronounced concentration during short periods of the year create imbalances manifested in excess of humidity, with all the implications that they imply in the dynamics of the environments. They intervene directly in the mechanisms of erosion and flooding and influence the effect of water aggressiveness at the watercourse level. The impact of these phenomena on environments is all the more important as the majority of slopes are bare and subject to strong human influence. These mountains are an old demographic home where the components of the physical environment have undergone significant changes, of which man bears a large share of responsibility. Similarly, the accelerated and uncontrolled human occupation of the urban peripheries, located downstream of the basins, increases the vulnerability of these environments to the hydrological hazards that threaten several peripheral sites in the city of Taza.

\subsection{Climate aggressiveness: a source of risk}

Despite the recurring droughts that characterized the last decades, some years remain largely wet with occasional torrential rains that discharge large amounts of water in short periods. These exceptional events are related to weather situations due to oceanic disturbances or only to localized thermo-convection storms.

The study of the annual rainfall evolution since 1970 to 2016, for the two stations of Taza and Had Msila, shows the very irregular nature (specific to the Mediterranean climate) of the rainfall in this Prerifan region. The periods of drought are more homogeneous and are marked by an almost uninterrupted succession of deficit years (from 1980 to 1994). The wet periods are often interspersed with dry years that can sometimes be very severe (this is the case for 1998 and 2007). However, the last phase of the series is clearly marked by records that show a real increase in the cumulative rainfall of the years 1996, 1997, 2003, 2009 and 2010 (figures 2a-2b-3a-3b).

The statistical study of daily rainfall recorded at the Taza and Had Msila stations during this period shows that the region is subject sometimes to maximum daily heights exceeding the $100 \mathrm{~mm}$ threshold, which are often the origin of hydrological dynamics with particular destructive power. These extreme phenomena are assimilated in some cases, but with a smaller magnitude, to heavy precipitation events (HPE) which affect frequently the western Mediterranean basin and which are part of the major natural risks causing serious consequences for environments and populations (Romero, Doswell III, Ramis, 2000; Argence, 2008; Sauvage, 2019).

These daily extremes can reach very significant morphogenetic records. Very demonstrative examples can be cited: $101 \mathrm{~mm}$ on 30 January 1987 in Had Msila (33.3\% of the monthly module) and $113 \mathrm{~mm}$ in Taza on March 14, 2004 (61.7\% of the monthly module). Besides, these maximum daily rains, considered crucial for the dynamics of surfaces, field observations have shown us that rains of lower but successive heights can also generate erosive processes and large-scale floods. Very significant records can be achieved in consecutive days. In the Had Msila station, $156 \mathrm{~mm}$ were recorded in only 2 days, from 21 to 22 December 1981; this quantity constitutes $50 \%$ of the monthly module which was $313 \mathrm{~mm}$. The same station received $175 \mathrm{~mm}$ in 3 days in January 1987 and $157 \mathrm{~mm}$ in January 1996 (Tribak, 2006). Similarly, the Taza station recorded $168 \mathrm{~mm}$ in 5 consecutive days in January 1996. High hourly intensities characterize certain rainfall events that produce large runoff coefficients. They are generally very high for short durations, but weaken once the durations become longer. The maximum intensities in 5 minutes reached very high records $82.2 \mathrm{~mm} / \mathrm{h}$ on 29/01/1986 and $55.5 \mathrm{~mm} / \mathrm{h}$ on 7/11/1987. Exceptional maximum intensities greater than $100 \mathrm{~mm} / \mathrm{h}$ correspond to the very severe storms of early autumn; they cause considerable damage, as was the case on 29/09/97 when a maximum intensity of $102 \mathrm{~mm} / \mathrm{h}$ was recorded (Tribak, 2006).

The occurrence of these events, which give very large quantities of water in a few days, or even in a few hours, is related to localized storms of thermo-convective origin or to oceanic disturbances. 


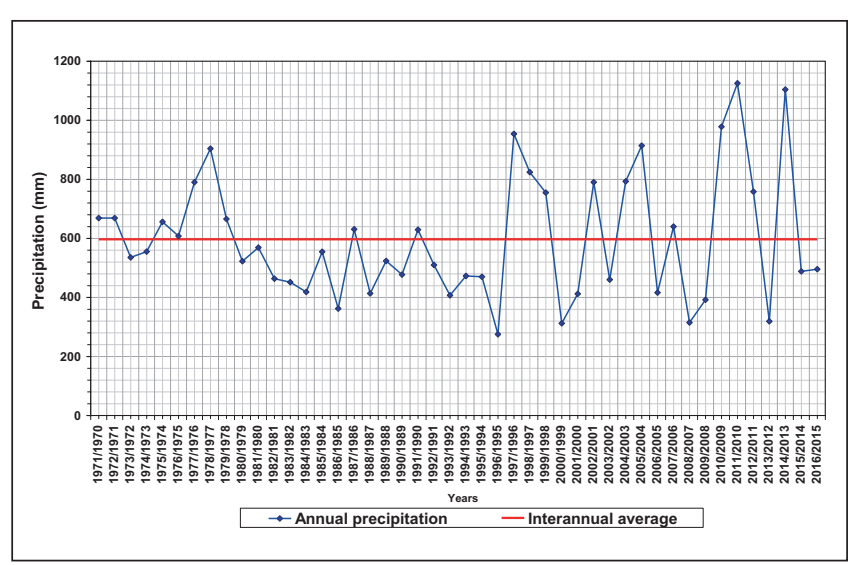

Figure 2a. Interannual variability of rainfall (Taza Station 1970-2016). Source: Centre de travaux agricoles - Taza).

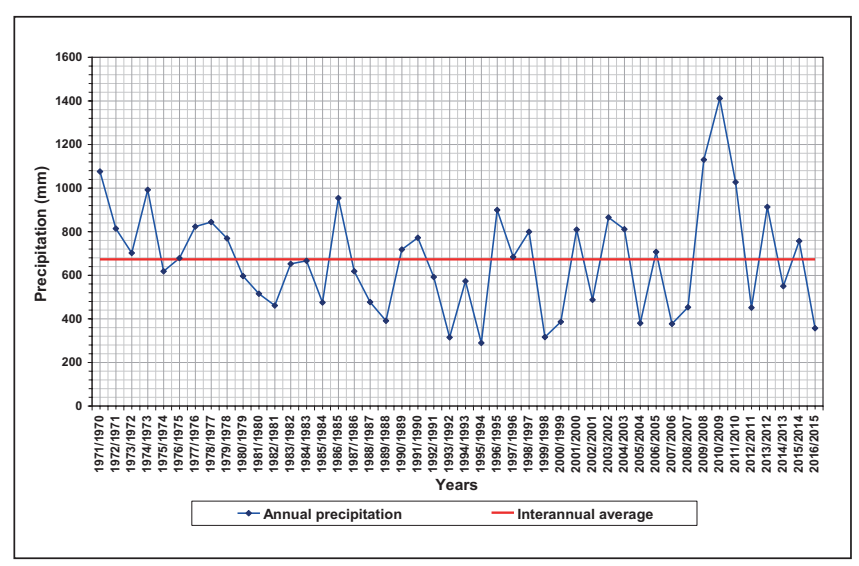

Figure 3a. Interannual variability of rainfall (Station Had M'sila Station 1970-2016. Source: Centre de travaux agricoles - Had M'sila).

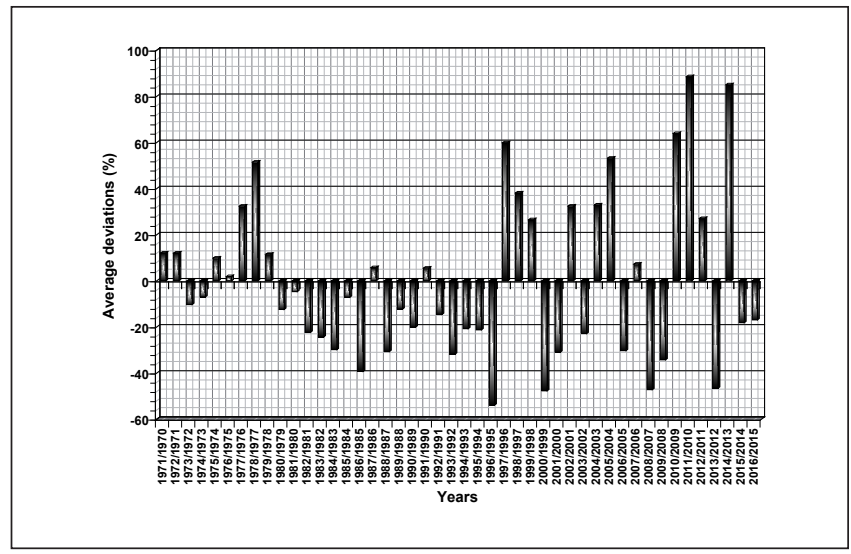

Figure 2b. Annual rainfall: average deviations (Taza Station 1970-2016). Source: Centre de travaux agricoles - Taza).

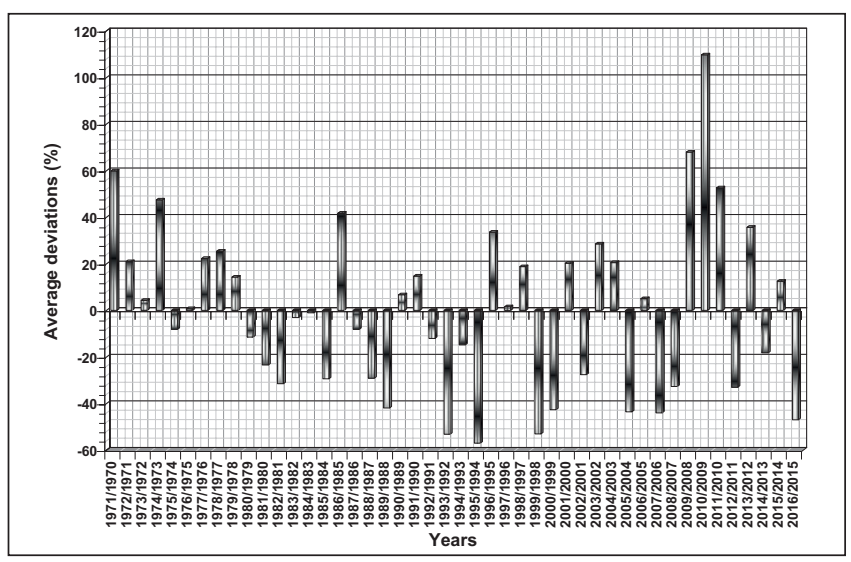

Figure 3b. Annual rainfall:average deviations (Had M'sila Station 1970-2016. Source: Centre de travaux agricoles- Had M'sila).

A - Stormy rains of thermo convective origin are fairly frequent in late summer or early autumn; they generate very exceptional rainfall both in quantity and intensity. Important water quantities can fall in just a few hours after long periods of summer drought. Very significant examples were recorded in the prerifain region during the years 1995, 1997, 2000, 2002, 2007, 2008 and 2010. The violent nature of these rains gives them very high potential for flow and erosion, especially when they occur during the dry period. Their impact is decisive on the ablation and transport capacity at the hydrographic network level; they favor very high flow coefficients which cause disastrous floods.

The occurrence of these heavy rains during the warmest months suggests a thermo-convective origin during this period when the anticyclonic situations are dominant. Vertical instabilities in the continental and maritime tropical air masses result from the presence of polar air at altitude, in the form of a small southward incursion of cold drops (Janati Idrisi, Mazoz \& Smihi, 2017). This gives stormy weather which produce very abundant rains on the mountain areas in Morocco. The stormy episode of September 27, 2000, for example, caused a real disaster in the region. Abrupt and concentrated rains totaling respectively $38 \mathrm{~mm}$ and $31.7 \mathrm{~mm}$, in the two prerifan stations de Ain Boukellal and Bab Chhoub in the north of Taza, were discharged on the region between $15 \mathrm{~h} 45 \mathrm{~min}$ and $17 \mathrm{~h}$ (DRH-Sebou, 2000; Akdim et al., 2003; Taous et al., 2010). Their occurrence is linked to a stormy activity on the Prerif and the Eastern Middle Atlas which was produced through the combination of geographical and thermodynamic factors (figure 4a-4b). Indeed, warm winds from the Saharan thermal depression in the south, forced to rise on the south-eastern slopes of the Prerif and the Middle Atlas, came into contact (collision) with Mediterranean maritime influences. This mountain stormy weather is supported by a shift of a cold altitude anomaly of the north-east sector from Central Europe. The 
presence of a small cold drop $\left(-15^{\circ}\right)$ animate the convection system from which the formation of a ripple that attracted the hot air masses of the South-East and the fresh ones coming from the north-east, over all the eastern Morocco. Vertical contrasts also play a decisive role in a such situation, due to the large thermal differences between the two atmospheric levels 500 and $850 \mathrm{hPa}$ of around $30^{\circ} \mathrm{c}$. similarly, the proximity of mountain obstacles remains favorable to the activity of orographic and thermodynamic lifts. Thus, thermal contrasts between the lower and upper strata resulted in abundant precipitation throughout the Prerif and Middle Atlas mountains near Taza.

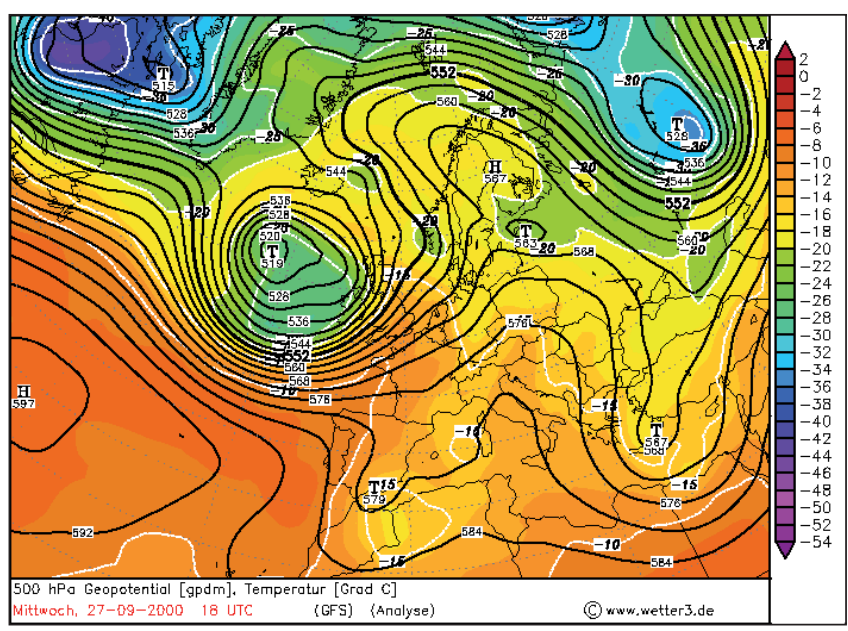

Figure 4a. Convective Thunderstorm Situation (27-092000) geopotential height $500 \mathrm{hPa}$ at $18 \mathrm{~h}$ UTC. Source: http://www1.wetter3.de/archiv_gfs_dt.html

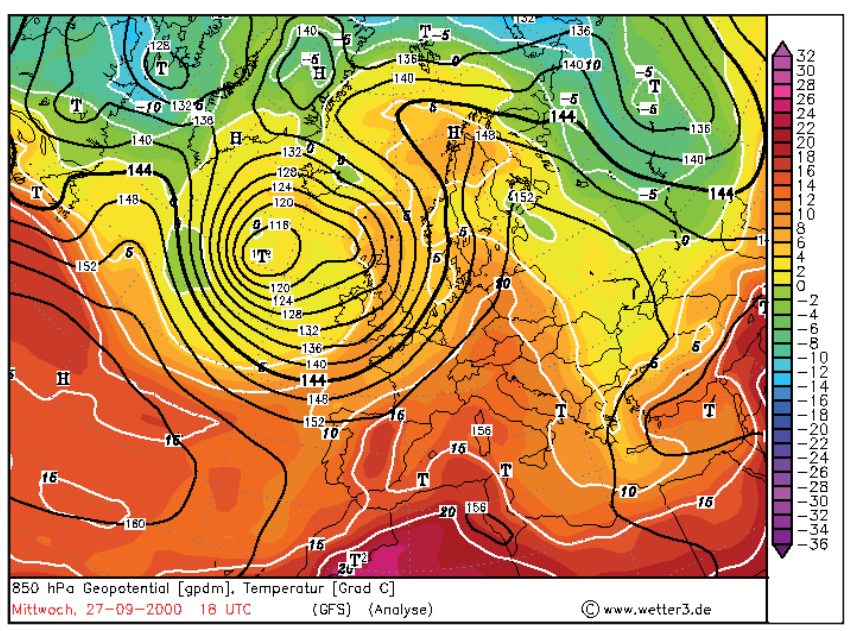

Figure 4b. Convective Thunderstorm Situation (27-092000) geopotential height $850 \mathrm{hPa}$ at $18 \mathrm{~h}$ UTC. - Source: http://www1.wetter3.de/archiv_gfs_dt.html

B - Very rainy daily episodes or in consecutive days related to oceanic disturbances also constitute a source of risks on several levels. Genetically, these exceptional rain events, which persist for a few days, are generally linked to oceanic disturbances that hit northern Morocco in the wet season.

The disturbed currents coming from the sectors west - north - west constitute the most frequent systems which cause abundant rains on the North of Morocco. They are generally related to the displacement of the polar front, which takes southern positions during the wet season. Generally at altitude ( $500 \mathrm{hPa})$, the jet stream creates wide undulations at the level of the northern hemisphere and consequently, a great cold valley above the Atlantic and Western Europe. The result is a deep and persistent cyclonic situation in the North of the Atlantic, whose flow reaches and largely covers Morocco, causing a very unstable weather and abundant rainfall for a fairly long time.

The situation of March 13, 2004 can illustrate this example of a cyclone event. We can clearly see in (figure 5) the existence on the North Atlantic of a depression well dug and wedged between two anticyclonic cells. The juxtaposition of these cells at the level of the Moroccan coasts promotes the spread of the low pressure corridor and its concentration at the level of Morocco and then the liberation of its wet potential on March 14, 2004. This explains the abundance of rains that have fallen on the region from March 13th to 15th: $141 \mathrm{~mm}$ at Taza with $113 \mathrm{~mm}$ for the day of March 14th; $214 \mathrm{~mm}$ in Oujda, $204 \mathrm{~mm}$ in Berkane and $116 \mathrm{~mm}$ in Nador (Ben Brahim, 2006). These violent and concentrated rains were the source of disastrous floods in the region of Taza and all the East of Morocco.

Similarly, the situation of 29-01-87 shows a vast depression on the North Atlantic, which directs towards Morocco flows from W to NW (figure 6). The Azores anticyclone is shifted south of the $35^{\text {th }}$ parallel. The weather in Morocco is very unstable; it is under the influence of a very active disturbance whose cold sector is constituted of humid maritime polar air and the hot sector constituted of maritime tropical air, coming from the Azores anticyclone. Rainfall is very abundant on the West and the North of the country; the two stations of Taza and Had Msila recorded, respectively, from 29 to 31 of January, 159 and $174 \mathrm{~mm}$. 


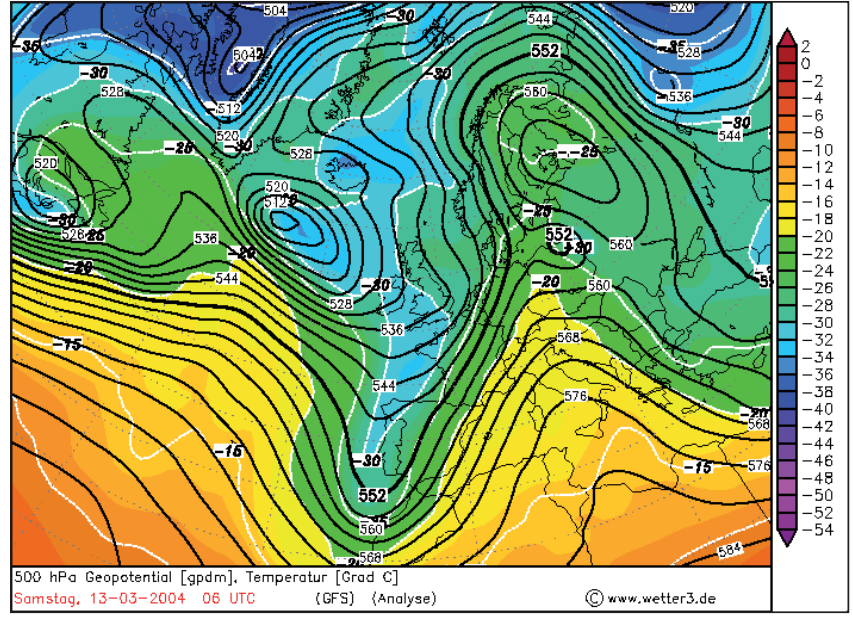

Figure 5. Disturbed situations of the West North West sector (13 - 3 - 2004) geopotential height $500 \mathrm{hPa}$ at $6 \mathrm{~h}$ UTC.

Source: http://www1.wetter3.de/archiv_gfs_dt.html

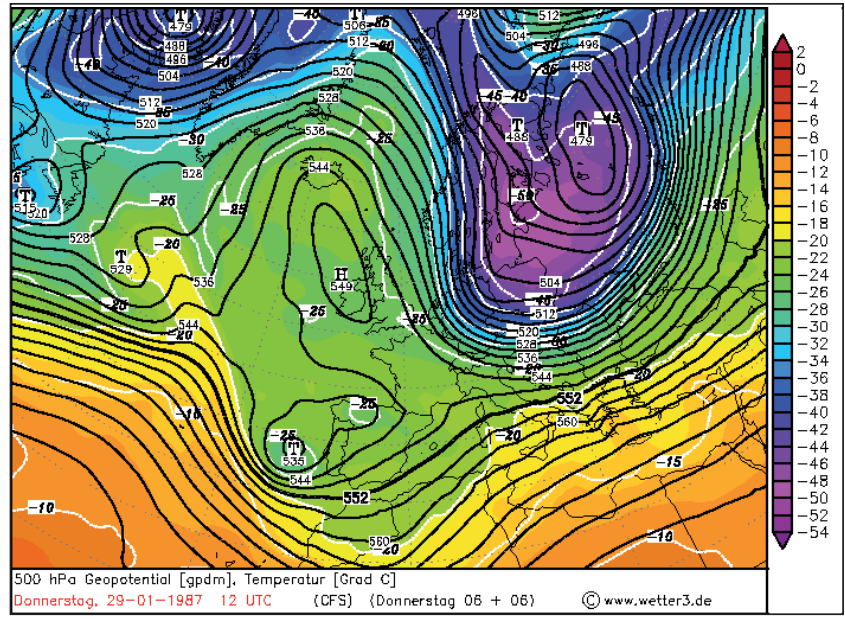

Figure 6. Disturbed situations of the West North West sector $(29-01$ - 1987) geopotential height $500 \mathrm{hPa}$ at $12 \mathrm{~h}$ UTC.

Source: http://www1.wetter3.de/archiv_gfs_dt.htm

Moreover, disturbances of the north and north-east sector can also generate abundant rains in consecutive days. The disturbed currents coming from the north result from a wide low-pressure zone over the Mediterranean and Western Europe due to the displacement of the polar air. The strong cyclonic flows that reach Morocco and all of North Africa cause abundant rainfalls that persist a few days (figure 7). Thus, from January 29 to February 9, 1986 the region is subject to abundant rains which totaled $196 \mathrm{~mm}$ at Taza and $256 \mathrm{~mm}$ at Had Msila over 12 consecutive days. These rains result from a series of disturbances of the $\mathrm{N}-\mathrm{Ne}$ sector, directed towards Morocco by a wide depression which covers Western Europe, the Mediterranean basin and the Iberian Peninsula. Thus, the situation of 31/01/86 shows that Northern Morocco is subjected to a wide and deep depression, centered on the northwestern edge of the Mediterranean. The Azores anticyclone, centered at NW, narrows as it shifts to the west; another anticyclone centered on the Scandinavian countries limits the depression to the North. This cyclonic depression which allows the passage of the northern air masses, maintains a disturbed and unstable time in Morocco. It is accompanied by heavy rains which gave on January 31, 1986, $41 \mathrm{~mm}$ in Taza and $54 \mathrm{~mm}$ in Had Msila with a decrease of the temperatures. This situation persists until February 11 with a gradual shift of the depression, sometimes to the East sometimes to the West, causing heavy rains in the north of the country.

It is also important to note that disturbed weather in the southwest sector can cause copious rainfall during the winter. Air movements circulating on the Atlantic Ocean, along the Moroccan coast, allow the digging of a cold valley (figure 8). Cyclogenesis is therefore associated with polar air masses in the south (Janati et al., 2017), which allows the establishment of strong disturbances of the south-west sector favoring abundant rainfall which gave $46 \mathrm{~mm}$ to Taza for the only day of February 17th, 2010.

\subsection{Impacts of human pressure}

several studies have shown the close link between social dynamics and the environments dynamics in different parts of the Mediterranean basin (Benchetrit, 1973; Desplanques, 1969; Néboit, 1983; Maurer, 1990; Maurer,1991; Maurer,1996; Lyrintzis \& Papanastasis, 1995). For these authors, man influences in many ways on the dynamics of environments. Its role is manifested by a progressive alteration of the natural protective vegetation of the slopes and by a land occupation, unsuited to the climate and morphological context data. For Néboit (1983), the current fragility of Mediterranean environments is also a legacy of history, "... Man imprints his mark on the soils and modeling at a historical rate.". The work of Lyrintzis (1995) on the Psilorite Mountains in Crete shows that the anthropogenic impact on the degradation of these environments dates back to the Neolithic, "... Human activities, particularly pastolarim, farming and hunting, have damaged the en- 
vironment in Psilorites since the Neolitic period... ". Desplanques (1969) in his study of the Umbrian countryside in Italy highlights the close relationship between the clearing and exploitation of steep slopesand the speed of evolution of erosive phenomena. "... indiscriminate clearing on steep slopes, practice of temporary agriculture with long fallow, subsistence economy that seeks to extract the maximum of food from the soil, it was enough to unleash erosion..."

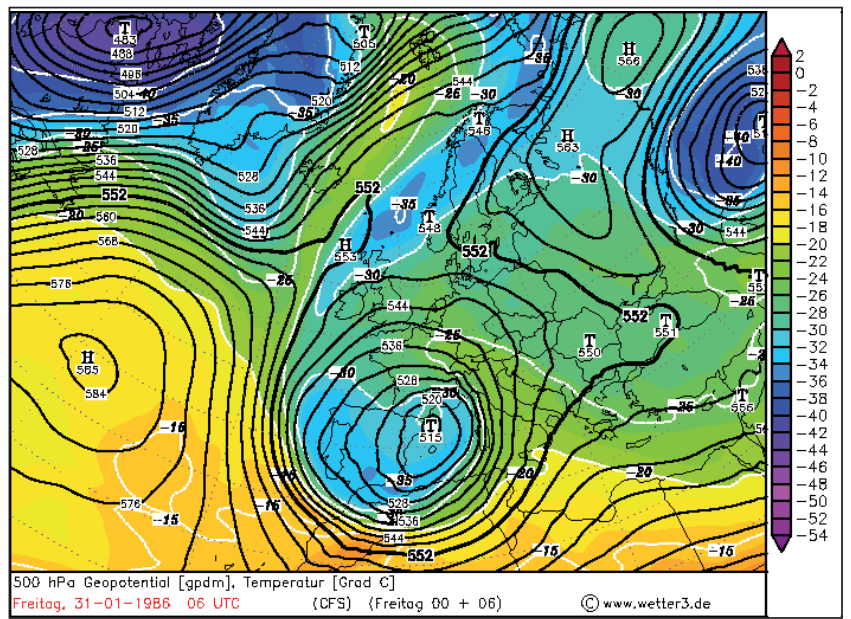

Figure 7. Disturbed situation of the North and North East sector - geopotential height $500 \mathrm{hPa}$ at $6 \mathrm{~h}$ UTC (31-01-1986). Source: http://www1.wetter3.de/archiv_gfs_dt.html

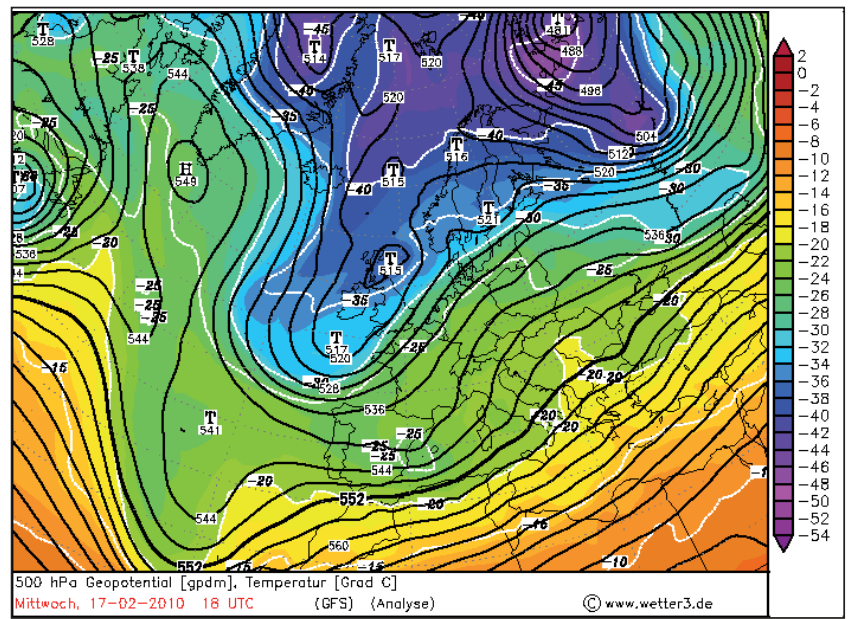

Figure 8. Disturbed situation of the West South West sector geopotential height $500 \mathrm{hPa}$ at $18 \mathrm{~h} \mathrm{UTC}(17-02-2010)$. Source: http://www1.wetter3.de/archiv_gfs_dt.html

In the mountains of the Moroccan Rif, the links between the activities of human societies and the instability of the environment can only be obvious. Maurer (1990) points out that the asylatic formations that still cover a few peaks of the Rif Mountains derive from the destruction of the forest since several centuries. In fact, these mountains, which are an old demographic home, have been settled for a very long time. Successive societies in the region over the centuries bear, therefore, a great responsibility in the disturbance of the ecosystems and the modification of the components of the physical environment (Tribak, 2000).

Researches conducted during the last decades, in different regions of Morocco, confirm the extent of these transformations in all Moroccan countryside during the 20th century, with serious consequences for environments and societies. The traditional structures as well as the old socio-spatial organization have been largely shaken, and the balance, long maintained between the needs of the populations and the local resources, deeply broken (Kerbout, 1990; Jennan, 1990; Maurer, 1996; Benchrifa,1995). If the colonial era was marked by an alteration of the traditional model of organization of resource use; the period of independence shows a strong population surge leading to an exacerbation of the human influence on the environment.

Indeed, since the beginning of the 20th century the Rifain mountains are subject to deep changes whose impacts on environments are enormous. The alteration of the traditional socio-spatial organization model and the displacement of the population towards the marginal zones, which accompanied the colonization, were the starting point of a generalized imbalance affecting the environments and the societies. The concentration of agricultural land in the hands of an elite of powerful landowners had forced peasants to undertake extensive clearing operations; these were only possible in marginal areas with steep slopes.

Similarly, the delimitation of the forest estate, carried out under the protectorate, was at the origin of a recrudescence of the clearing actions affecting almost all the forest areas in Morocco, in the Rif (Grovel, 1996) also in the Atlas (Jennan, 1996). In this region of the Prérif, the peasants, threatened to lose the forest rangelands, fastened to clear the maximum of space before the beginning of the delimitation operations, with the aim of enlarging their small properties and to procure spaces for flocks. Our field surveys confirm that certain notables in the region have not ceased, even after delimitation, to carry out large-scale clearing operations of natural forests, using necessarily local labor, to increase their land capital. In this context some 
forests were completely destroyed during the 1940s and converted into culture land for the benefit of speculators. These actions contributed to the acceleration of runoff and erosion on the slopes.

The demographic upsurge, which intensified with independence during the 1950s, had the same effects. The tendency to increase population numbers and densities is very clear after the independence, without however excluding a few moments of slowdown or even regression characterizing certain phases (HCP, RGPH, 1982, 1994, 2004). The total evolution over the entire period (1960-1994), which is of the order of $36.5 \%$, shows that the population has increased, over thirty years, at a rate much lower than that of the Moroccan population. However, a clear difference opposes the various periods; although the period 19601971 has been at a significant rate of change (18\%), the second period 1982-94 has, on the contrary, shows a reduction in the number of rural population. However, local population pressure remains high in 2004; densities still exceed the $60 \mathrm{~h} / \mathrm{km}^{2}$ threshold in all municipalities in the Taineste district (HCP-RGPH, 2004).

The very high rate of growth characterizing the early 1960 s is a phenomenon almost general throughout Morocco after independence. It has the direct consequence of excessive pressure on resources, unfortunately unable to provide the incessant needs of a growing population. Our field surveys show that the need of the land was such that the peasants were forced to push the agricultural work as far as possible and overexploit the conquered land at the expense of woodland. The peasants in crisis, far from worrying about the consequences of their actions, attacked the forests, already degraded, which still covered high massifs located in the north of the region. The conquest of new cultivated lands and the extension of their surfaces, irrespective of the nature of the land and the degree of slopes, was the objective, in the search for means of subsistence, for a destitute and growing population.

In this context some forests were totally destroyed during this period and converted back to farming land. Old population confirm the intensity of clearings during this period and regret the time during which these forests provided them with grazing lands, the necessary wood and even hunting prey (Tribak, 2000). The current use of space reflects the extent of human influence and agrarian conquest. Land structures, shaken by various historical events, introduce varieties of occupation, some of which are incompatible with the conditions of the physical environment (Tribak, 2000). Similarly, demographic pressure has transformed forest landscapes into a mosaic of cereal plots associated with degraded scrub (matorrals) (figure 9). Protective natural forest slopes are almost destroyed; they currently cover only a few mountain peaks in the region. They represent respectively $1.84 \%$ and only $1.32 \%$ of the total area of the Tleta and Tarmast sub-basins of Wadi Larbâa. However, croplands, occupying respectively $60 \%$ and $34 \%$ in the two sub-basins, extend even on the steepest slopes (Tribak et al., 2017). The overexploitation of the conquered land, if we take into account the lack of fertilizing inputs, the elimination of fallow and the overgrazing activities, led to a reduction in their fertility and to a total sterility of certain plots which were abandoned later. Examples of abandoned sterile plots are increasing throughout the region where poor soils are still intensely washed away by erosion. This abandonment of agricultural plots has been accentuated recently, because of the migratory movements which intensified from the 1980s.

Moreover, the accelerated and uncontrolled occupation of the urban peripheries, located downstream of these basins, amplifies the vulnerability of these environments as to the hydrological hazards that threaten several sites of the Taza agglomeration. Indeed, faced with very difficult situations, because of recurring droughts, the failures of the agro-pastoral system and the precariousness of the living conditions, the Rifan peasants were forced to look for solutions outside their environment. This has resulted in migratory movements whose forms and magnitude remain variable from one period to another. A large mass of populations leaves repellent mountain areas in hopes of finding elsewhere the means to live more conveniently (Tribak et al., 2019). The prolonged drought period (1980 - 95) accentuated the emigration processes already started during the previous decades in Moroccan rural areas. The city of Taza, as chief town of the region, has been a main destination for the masses of emigration. Since the second half of the 70s, the influx of rural people to the city has delivered large areas of peripheral zones to the proliferation of substandard housing. Indeed, during the last decades the city of Taza has engaged in a process of rapid growth; it currently covers a built area of approximately $863.11 \mathrm{ha}$. According to the 2015 SDAU, the built area of Taza increased from 237.93 ha in 1980 to 340.45 ha in 2000 . During this period we assist to the appearance and extension 
of non-regulatory neighborhoods, such as Al Malha, Asdour and Chlouh, which developed in the northern peri-urban area of the city, on both sides of wadi Larbâa (Royaume du Maroc, SDAUT 1992; SDAUT, 2015). Its population has also increased rapidly: the number of inhabitants has increased from 31966 in 1960 to 120171 in 1994 and 148456 in 2014 (HCP - RGPH, 1994, 2004, 2014).

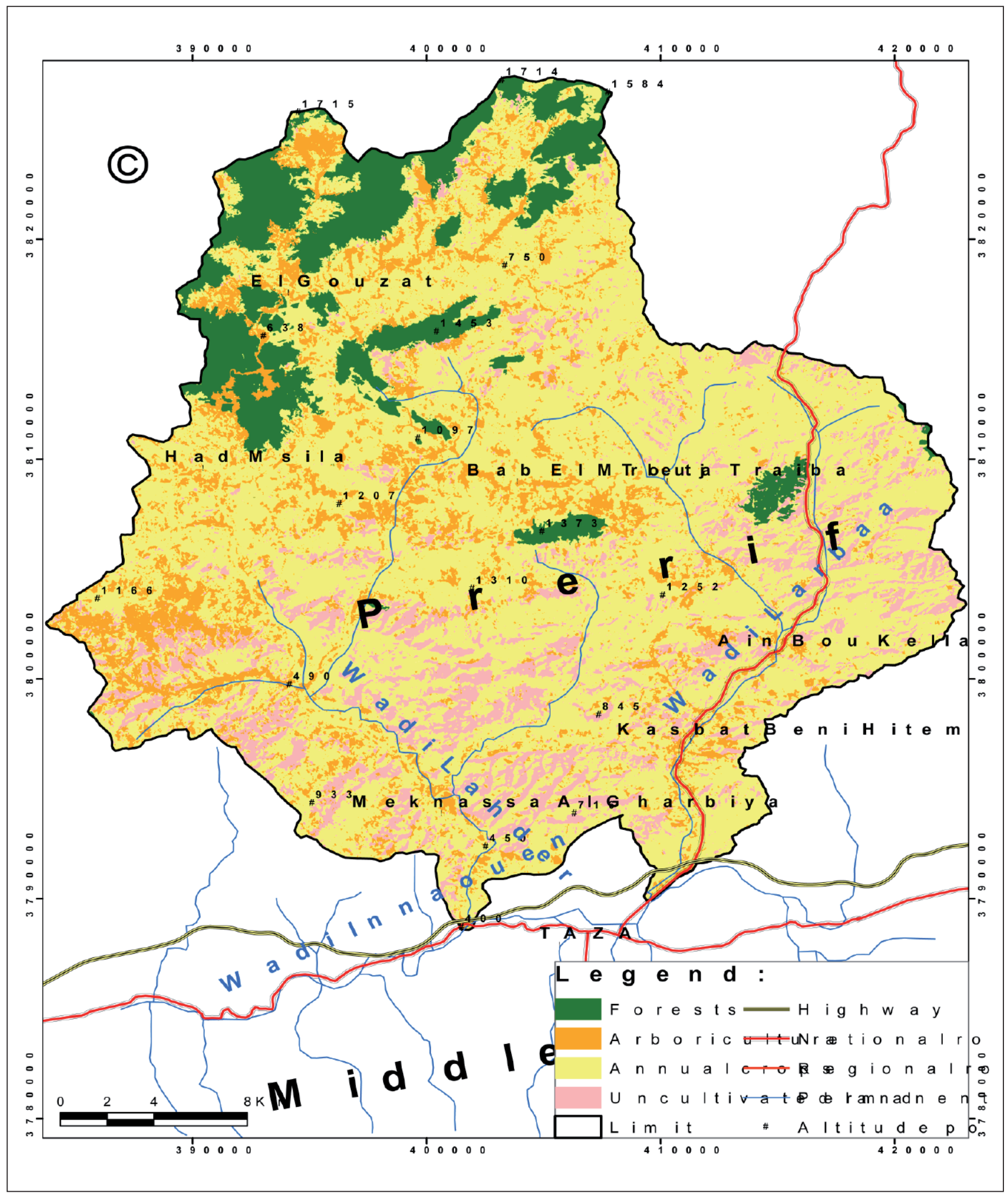

Figure 9. Current land use in the Prerifan Zone (Wadi Lahder and Larbaa catchments). Source: https://earthexplorer. usgs.gov - LandSat - October 8th, 2017-resolution $30 \mathrm{~m}$. 
These emigrant flows were composed mainly of poor strata seeking refuge in peripheral areas or in old houses in the medina, shared with other households. Thus, the progressive concentration of the population in the city reflects the importance of the dynamics that it has experienced in recent decades, to the detriment of the surrounding rural areas which clearly display a growth rate, which has been steadily declining since the 1980s. This demographic transition, characterizing the last decades, has been associated with a development of the urban fabric in an anarchic and uncontrolled way, which explains the scale of the installations in carrying risk zones (Tribak et al., 2018). Rural exodus flows, accelerated in times of drought, have contributed significantly to the increased vulnerability of the periphery, as most of the new urban entities were in non-regulatory areas and generally exposed to multiple risks. Building pressure has forced new arrivals, driven by harsh living conditions in the countryside, to build in sites where the risk is potentially high. Thus, the peri-urban spaces of the Taza city constitute an area where the demographic surplus of the city was poured out as well as the migrants who were unable to settle inside the city.

This uncontrolled human occupation has significantly worsened the intrinsic fragility of these sites. The lack of basic infrastructure, the overdensity, the elevation of some buildings, the non respect of building standards and the lack of maintenance constitute some factors that amplify the vulnerability of these environments to natural hazards (Tribak et al., 2019). Field surveys show that most of the chaotic neighborhoods of the Chlouh, Al Malha and Asdour were developed during the 1980s and 1990s during which water scarcity was excessive in most of the surrounding prerifan countryside (Tribak, 2000). These neighborhoods, located on the sides of wadi Larbâa, are affected almost every year by disastrous floods (Agence Urbaine Taza, 2000; Agence Urbaine Taza, 2002; DRH, sebou, 2000; Akdim et al., 2003, Taous et al., 2010; Layan, 2013; Zyane, 2015).

\subsection{Erosive manifestations and sediment production}

The prerifan-mountains are subject to a very intense erosion processes. Most of the slopes, almost completely denuded, undergo the degrading effect of rainfall events. The intensity and distribution of erosion phenomena vary from one area to another, depending on surface resistance, the nature of slopes and their exposure, the density of vegetation cover, and the nature of human activities.

The analysis of physical and human parameters acting on the spatial distribution of hydric erosion within the region allows defining a number of environments that juxtapose but, which differ in their physical characteristics and their morphodynamic evolution. Thus, the spatial distribution of erosive phenomena shows that sheet erosion on the slopes is less important than the gully erosion that produces most of the sediments in the region. These results are consistent with some empirical studies conducted in other regions of the Rif. According to the study carried out by B. Heusch (1970) in the marly basins of the Western Prerif, the erosion reports show that the slopes lose a very small amount of soil by surface runoff in comparison with that provided by gullies and riverbanks. This quantity, according to the results of the 1967-1968 campaign, is $3 \%$ of the total for the slopes, $52 \%$ for the badlands and $45 \%$ for the banks erosion. Likewise, work on mapping erosion forms, carried out by the Ministry of Agriculture, Rural Development and Water and Forests (MADREF), shows an average specific degradation of $800 \mathrm{t} \mathrm{ha}^{-1} \mathrm{year}^{-1}$ for the forms of riverbank undermining, $79 \mathrm{t} \mathrm{ha}^{-1}$ year-1 for gullied areas subject to solifluxion, and only $5.6 \mathrm{t} \mathrm{ha}^{-1}$ year-1 for slopes subject to sheet erosion (MADREF, 1994). Gully processes, on marly steep slope, are able to remove significant amounts of land annually from the topsoil. Quantification tests at the level of certain linear incisions show enormous quantities of ablation, more particularly, on plots located on less evolved soils of erosion on a steep slope (36 ${ }^{\circ}$ slope); losses are estimated at about $140 \mathrm{t} \mathrm{ha}^{-1}$ year-1 (Tribak et al., 2012).

The erosion scars resulting from the gulling processes are spectacular in the region, due to the considerable extension of the bare marly soils and the importance of the superficial formations that derive from them (photo 1). Thus, the badlands are characteristic landscapes, widely spread in the region where they correspond particularly to southern exposure slopes. Their activity involves the role of exposure as well as the physicochemical and mineralogical properties of miocene marl (Imeson et al., 1988; Tribak et al., 2012). The rare research conducted in the region agrees that the evolution of the Badlands slopes began very early. 
In the south Rifain corridor, Mathieu (1977) assumes, by analyzing deposits of recent terraces of Boulejraf wadi, that the evolution of badlands in this sector dates back to the Tensiftian periode. Similarly, the C14 dating of well-developed recent terraces deposits, near the badland landscapes of the Upper Tarmast Wadi, is an argument that can help us to approximate the beginning of evolution of these phenomena. These deposits, dated at 3571 B.P, show that the appearance of badlands in this area probably dates back to this date, which corresponds to a recent episode of the Rharbien, (the dated level is $1.7 \mathrm{~m}$ from the base of the terrace) (Tribak, 2000). The considerable thickness of these deposits $(5 \mathrm{~m})$, their silty texture as well as their color suggest that they come from the marly formations, bordering the middle and upper courses of the Tarmast wadi, currently shaped by spectacular landscapes of bad-lands that continue to evolve (Tribak, 2000). The probable appearance of badlands at this time would be linked to climatic variations affecting the Rharbian which appears, according to Wengler 1993, as a globally humid interstationary period interspersed with more arid episodes during which erosion dominates. Nevertheless, the role of man cannot be totally excluded; the major effect of climatic variations would have been aggravated by a possible human presence since that time in the region. The current evolution of these badlands by different processes constitutes an important source of sediment production evacuated towards the main collectors.

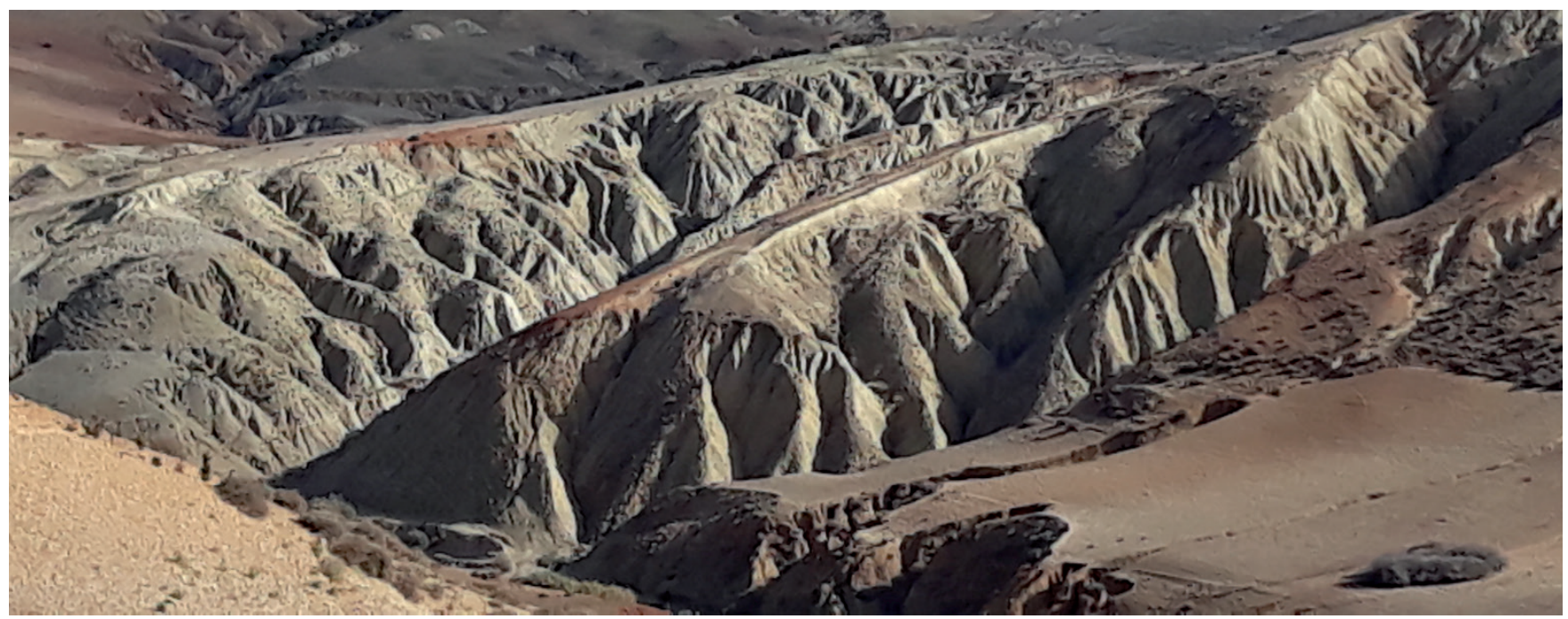

Photo 1. Badlands landscapes in Miocene marly formations. Their rapid evolution by physicochemical processes allows evacuating huge quantities of sediments. Source: Cliché, Tribak, 2017.

The quantification of soil losses according to the modified Wischmeier universal equation (Wischmeier, 1976; Wischmeier, 1978; Renard et al., 1997; Bonn, 1998), shows both the extent of land loss in the region and their great variability from one sector to another. In the case of the marly basin of the Telata wadi (sub-basin of Larbâa Wadi), the weighted average loss by the surface is $61 \mathrm{t} \mathrm{ha}^{-1}$ year-1 (Abahrour, 2009; Tribak et al., 2009). The losses are greater in the Wadi Tarmast sub-basin where the RUSLE model has an estimated loss of $81 \mathrm{t} \mathrm{ha}^{-1}$ year $^{-1}$ (Tribak et al., 2015; Tribak et al., 2017). These results show excessive sediment production that exceeds the tolerance threshold. This remains closely linked to the considerable extension of fragile marly materials, as well as the predominance of strong and bare slopes. The spatial distribution of soil losses in the Tarmast sub-basin in 2014 shows that the class above $32 \mathrm{t} \mathrm{ha}^{-1}$ year ${ }^{-1}$ is predominant occupying $21.7 \mathrm{~km}^{2}(31.3 \%)$ of the basin area. This is likely related to the considerable extension of wastelands and bad lands where the sediment production is excessive. On the other hand, this class represents only $16.52 \%$ in the Tleta sub- basin, occupying an area of $19.97 \mathrm{~km}^{2}$, because of the small area of uncultivated and abandoned lands and the importance of arboriculture which records considerable extension on most slopes of 
the basin. The class of losses below $7 \mathrm{t} \mathrm{ha}^{-1}$ year-1 occupies $16.9 \mathrm{~km}^{2}(24.2 \%)$ of the total area of the Tarmast sub-basin and only $8.94 \mathrm{~km}^{2}(7.4 \%)$ in the Tleta sub-basin (Tribak et al., 2017).

The soil losses according to land occupations in 2014 shows that uncultivated and abandoned land still remain in the lead with $140 \mathrm{t} \mathrm{ha}^{-1}$ year-1 for the wadi Tarmast sub-basin and $108 \mathrm{t} \mathrm{ha}^{-1}$ year-1 for the same period for the wadi Tleta. Soil losses by type of occupation in 2014 for the Wadi Tarmast sub-basin; vary between 2,219 t ha $^{-1}$ year $^{-1}$ as the minimum value measured in forests and 140,106 tha-1 year-1 as the maximum value recorded for uncultivated and abandoned land. For the sub-basin of wadi

Tleta; losses vary between $1.89 \mathrm{t} \mathrm{ha}^{-1}$ year- ${ }^{-1}$ as the minimum value measured in forests and $108.26 \mathrm{t}$ $\mathrm{ha}^{-1} \mathrm{year}^{-1}$ as the maximum value recorded for abandoned and uncultivated land. The latter generally correspond to poorly evolved soils of erosion unprotected and located on marly steep slopes. The areas reserved for annual crops and arboriculture also show a high susceptibility to erosion with annual losses of $39.81 \mathrm{t}$ ha $^{-1}$ year ${ }^{-1}$ for Wadi Tleta and $31.11 \mathrm{t} \mathrm{ha}^{-1}$ year $^{-1}$ for Wadi Tarmast (Tribak et al., 2017).

In comparison with basins of the Rifan mountains, average losses are estimated in the Nakhla watershed in the Western Rif at $65 \mathrm{t} \mathrm{ha}^{-1}$ year-1 at the field level (Naimi et al., 2004), at 60 tha $^{-1}$ year ${ }^{-1}$ In the wadi Ouergha basin (Le landais et al., 1995), and at 55.35 tha $^{-1}$ year-1 $^{-1}$ in the wadi Boussouab basin (Sadiki et al., 2004). In the wadi Lebène basin (Prérif) the specific degradation is about 35 tha $^{-1}$ year-1 $^{-1}$ in wet conditions (Gartet, 1994). It is about $39 \mathrm{t} \mathrm{ha}^{-1}$ year-1, in the upstream of the Ibn Batouta dam, in the Telata watershed at the western Rif (Merzouk, Fenjiro \& Laouina, 1996). In the El Mellah wadi at Central Prerif average losses are estimated at $34 \mathrm{t} \mathrm{ha}^{-1}$ year-1 $^{-1}$ (El Laroussi et al., 2011). In wadi larbâa marly basin, at the eastern Prerif, it is about $45 \mathrm{t}$ ha $^{-1}$ year $^{-1}$ (Arari et al., 2019). For comparison within the Mediterranean basin, the application of the USLE model in different sub-basins of the Segura river (Murcia) gives erosion rates between 30.2 and $80.4 \mathrm{t} \mathrm{ha}^{-1}$ year ${ }^{-1}$ (López Bermúdez, 2003). Similarly, on the hills of Terrefort Laugarain, in the south of France, estimates of land losses according to the RUSLE model show that in the southern sector of the Hers valley $81 \%$ of the erosion values are higher than $60 \mathrm{t} \mathrm{ha}^{-1}$ year-1 $^{-1}$ and $70 \%$ of the values are between 31 and $60 \mathrm{t} \mathrm{ha}^{-1}$ year-1, thus representing $51 \%$ of the basin area (Morscell \& Fox, 2004).

Rainfall simulations carried out on micro plots using a rain simulator have shown that runoff on plowed plots is low compared to other types of land use because of surface roughness that exceeds $16 \%$ in all plots, and the predominance of open areas that can occupy up to $76 \%$ of the total area of these plots. In fact, the results show that infiltration rates are still very high on plowed land and very far from the rates recorded on abandoned or fallow land. This is true for the vertisols widely distributed in the basin as well as for the calcimagnesic soils (Abahrour, 2009; Tribak et al., 2012). Infiltration rates on plowed land generally remain above $50 \mathrm{~mm} / \mathrm{h}$, even at the end of the simulation; on the other hand, they go down to $15 \mathrm{~mm} / \mathrm{h}$ on abandoned land. This explains the low runoff rates on plowed land that can record values of less than 15\%, especially at the start of the simulation, particularly on vertisols. For comparison, experimental studies in the Telfifit basin in Algeria show that the work of deep clay soil reduces the runoff coefficient by about $90 \%$ (Gomer, 1992). Cultivation and plowing land modifies further the structure and permeability of the soil and its resistance to the rain erosivity. However, if plowing temporarily improves infiltration, it accelerates the mineralization of OM and weakens the resistance of aggregates to rain energy (Sabir, 2007).

Furthermore, the high values of turbidity on plowed land compared to other types of occupations reflect the importance of erosion and the production of sediment from these lands, despite the reduced rates of runoff. The volume of soil losses remains high in plots plowed during certain periods of the agricultural year; the quantities uprooted exceed $260 \mathrm{~g} / \mathrm{l}$ at the beginning of autumn on vertic clay soils (Abahrour, 2009; Abahrour, 2015). The concentration of solid load is especially high in early autumn due to the very degraded state of soil structures and the decrease in initial soil moisture. Soils pulverized and disorganized by plowing are easily entrained, even by processes of sheet erosion, which causes a depletion of the surface horizons in colloidal elements (clays, OM) and consequently, a reduction in soil fertility (Morsli, Mazour, Mededjel, Hamoudi \& Roose, 2004). A phenomenon that could modify the dynamics of water at the level of surface horizons and reduce infiltration to the benefit of runoff.

The seasonal distribution of infiltration rates shows very large values in early autumn exceeding $50 \mathrm{~mm}$ I $\mathrm{h}$ even at the end of the simulation; this is explained by the high roughness of the soil just after plowing 
and the predominance of open areas and the low humidity levels. On the other hand, in winter the values go down to less than $10 \mathrm{~mm} / \mathrm{h}$ due to the high humidity of the soils as well as the closing of the surfaces with the persistence of the rains. This therefore explains the very high coefficients of runoff during the winter season which can exceed $70 \%$ on strongly clay vertisols. However, at the start of autumn they do not exceed $25 \%$ at the end of the simulation; plowing which opens the surfaces and reinforces the roughness remains rather favorable to infiltration. Likewise, the evolution of the plant cover, following the saturation of the soil in rainwater, clearly influences the soil's ability to runoff and erosion processes; the rate of plant cover on the concerned plots is high in the spring, it ranges between $71 \%$ and $82.7 \%$. The comparison of these simulation data with field observations shows effectively, that the recently plowed land, unlike other types of land, shows low runoff coefficients in favor of infiltration in case of low or medium rain intensity. However, this relationship is reversed in the case of heavy rain, which can produce dense networks of incisions and mobilize enormous quantities of sediment.

These results show that the influence of human activities, through traditional land use systems, is very significant in terms of the nature of the flow infiltration and ablation processes. Plowed soils record low runoff coefficients compared to those of fallow or totally abandoned land. The combined effect of cropping techniques and plant cover on worked soils can significantly reduce runoff and erosion compared to abandoned land. It seems that the frequency and intensity of runoff on the different types of soil are largely explained by the parameters of the surface conditions (roughness, open surfaces, closed surfaces, covered surfaces, etc...). In case of less heavy rain, the high roughness gives the soil a higher infiltration capacity and an availability to remain open longer and a lower susceptibility to runoff and erosion (Morsli et al., 2012). In addition, the abandoned land, where the soil is bare, compacted and structurally degraded, shows a high frequency of runoff throughout the year and therefore, a significant production of sediment.

The interpretation of the erosion quantification and simulation tests result shows that the role of human activities and land use patterns is an important factor in the acceleration of erosive phenomena and the excessive production of sediments. The fields intended for annual crops intensely grazed, remain potentially very fragile to erosional processes. The cleared, bare and cultivated land is the site of various erosive processes and records significant rates of land loss. Otherwise, the progressive evolution of uncultivated areas and badlands in the region can be explained by the abandonment of certain sectors, which is a recent phenomenon linked to migratory movements within the region. The significant expansion of uncultivated land, exceeding 34\% in the wadi Tleta basin (period 2000-2014) is closely linked to the phenomena of agricultural land abandonment due to the accelerated process of rural depopulation. The lack of basic protection and landscaping work means that the abandoned plots become a favorable place for runoff and gulling. The rapid compaction of abandoned land, in the lack of any tillage favoring infiltration, allows a concentration of runoff leading to the appearance of dense networks of incisions. This structural degradation of the surface, which increases with time, controls largely the nature of the flows and the runoff coefficients become very high. Similarly, land losses, which are occasionally low in relation to the plowed field, have higher annual rates because of the high frequency of runoff throughout the year. Silty-clay regolith, developed on Miocene marls show, in fact, high runoff rates in late summer and early autumn that can exceed $68 \%$ with a solid load of $239 \mathrm{~g} / \mathrm{I}$ at the end of spring, $179 \mathrm{~g} / \mathrm{I}$ at the end of winter and $275 \mathrm{~g} / \mathrm{I}$ at beginning of autumn (Tribak, 2000; Abahrour, 2009). This clay regolith is sensitive to the shear forces which tear the soil from the bottom and allow the installation of gullies. The evolution of the gullies and their annual widening, by different morphogenetic process, makes it possible to produce landscapes of badlands which evacuate most of the sediments towards the main collectors.

It seems therefore, that the continuous and rational exploitation of the soil don't present any great erosive risks. But it is mainly bare, abandoned and overgrazed soils that cause the greatest damage when runoff spreads over steep and bare slopes and collects in gullies (Morsli et al., 2012). This is perfectly in line with our field observations, which confirm that the autumn rains, often intense and aggressive falling on bare and degraded soils, allow generating extreme flows and very high land losses. Intense networks of linear incisions appear on bare steep slopes. The floods of this season, generally very violent and of short 
duration, are very loaded with sediments threatening seriously infrastructures and urban sites downstream of the basin (photo 2).

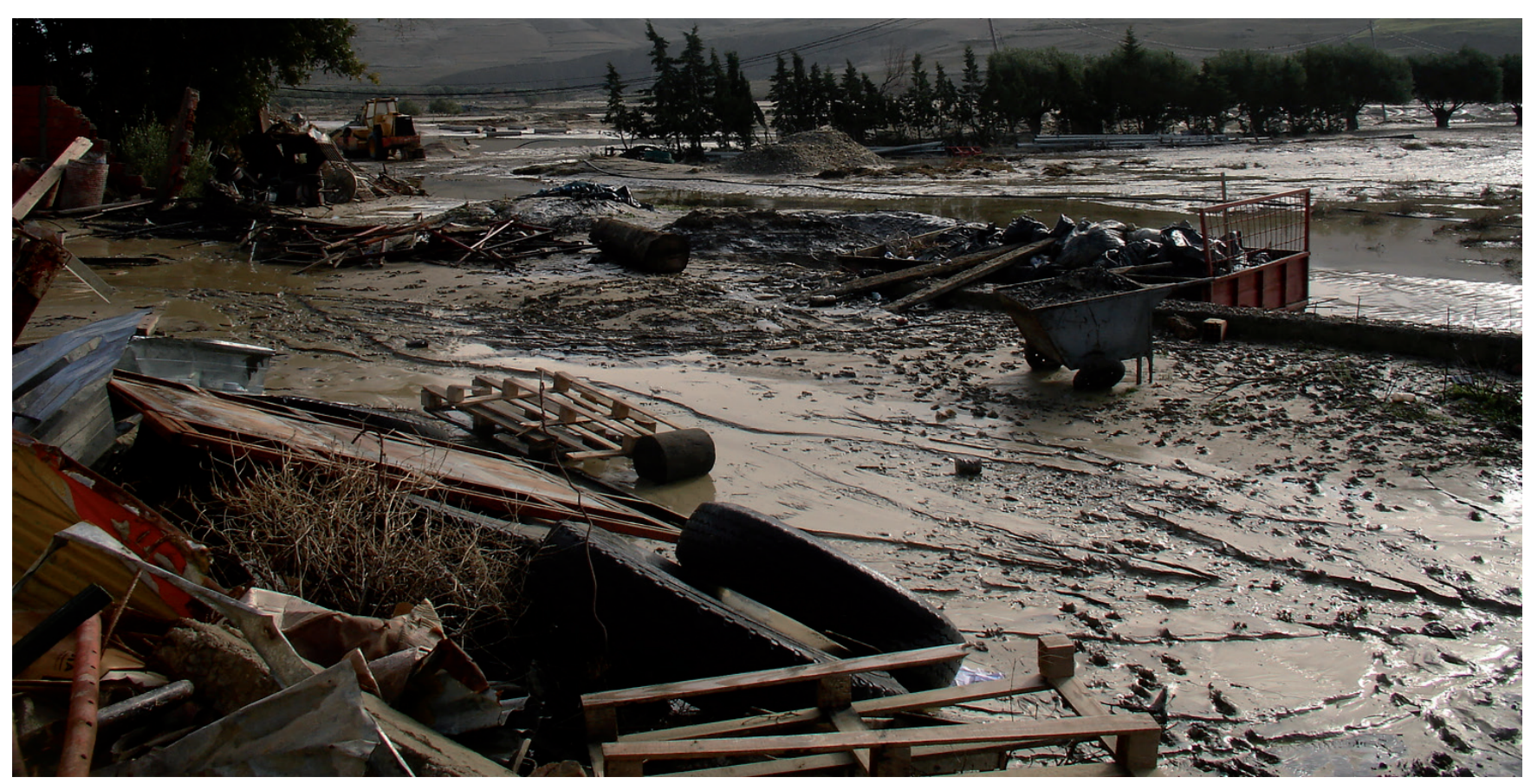

Photo 2. Impacts of the floods that affected the peripheral areas of Taza during the winter of 2010. Source: Cliche, Abahrour, 2010.

\subsection{Vulnerability of peri-urban areas to flood risk}

In addition, the rain events, previously analyzed, favor very high flow coefficients that cause significant floods. During these episodes, the main rivers in the region undergo sudden and catastrophic floods, which constitute a serious threat to infrastructure and peripheral urban neighborhoods. Indeed, for several decades, the agglomeration of Taza, located downstream of the wadi larbâa basin, has undergone a succession of events of large-scale floods which have generated serious disasters for the local populations.

Today, this city is living in a spatial dispersion of urbanization and the invasion of sensitive areas, resulting in the growth of amorphous and fragmented urban fabrics, where the risk of flooding is a crucial problem for the actors. The impacts of floods are not distributed evenly, they are very important in densely populated areas, where the stakes are multiple, and less important in sparsely populated areas. Indeed, the uncontrolled spread of the agglomeration during the last decades in the risk zones accentuates its vulnerability to the floods phenomena. Field observations show that the burst, sometimes uncontrolled, of urban space is framed by a number of dynamics that make these phenomena gain in magnitude and intensity. The emergence of new peripheral neighborhoods, occupied by poor social strata resulting from migratory flows, and their extension into risk areas, is an undeniable reality. The surrounding suburban areas of the city of Taza undergo very strong human pressure although their topography is rugged and unfit to support heavy human occupation. The flows of rural exodus, accelerated in drought periods, have contributed significantly to the increase in the vulnerability of the periphery, since most of the new installations were in non-regulatory construction zones and generally exposed to multiples risks. Promotional prices of land at the periphery have prompted the peasants to seek opportunities to settle without taking into account the risks involved.

As mentioned above, this urbanization incompatible with environmental conditions has been stimulated during phases of socio-economic and urban crises, where unhealthy housing has spread to the peripheries, corresponding to naturally unstable areas subject to natural hazards (Tribak et al., 2019). Many 
of these anarchic and unhealthy urban entities are built on the margins of regulation in the absence of a rigorous urban management policy. In other way, land speculation, which develops in moments of various crises, gives rise to spontaneous urbanization and contributes enormously to the proliferation of informal neighborhoods built on fragile lands to the detriment of urban tools (Royaume du Maroc -SDAUT, 1992). As a result, these peripheries constitute a belt of poverty and marginality that reproduces insalubrities and under-equipment at all scales (Tribak et al., 2019). It is mainly home to rural migrants who have not been able to settle in the city's equipped neighborhoods. Thus, the outlying districts: el Melha, Clouh, Asdour (figure. 10) located on the banks of the wadi Larbâa river and densely occupied by a population of rural origin, are frequently affected by flooding (Taous et al., 2010; Zyane, 2015). Field surveys and archives of the administrative services show that these districts have been submerged in a serious way, respectively during the years 2000 - 2002 - 2007, 2008 and 2010 et 2013 (Agence Urbaine Taza, 2000; Agence Urbaine Taza, 2002; DRH sebou, 2000; Taous et al., 2010; Layan, 2013).

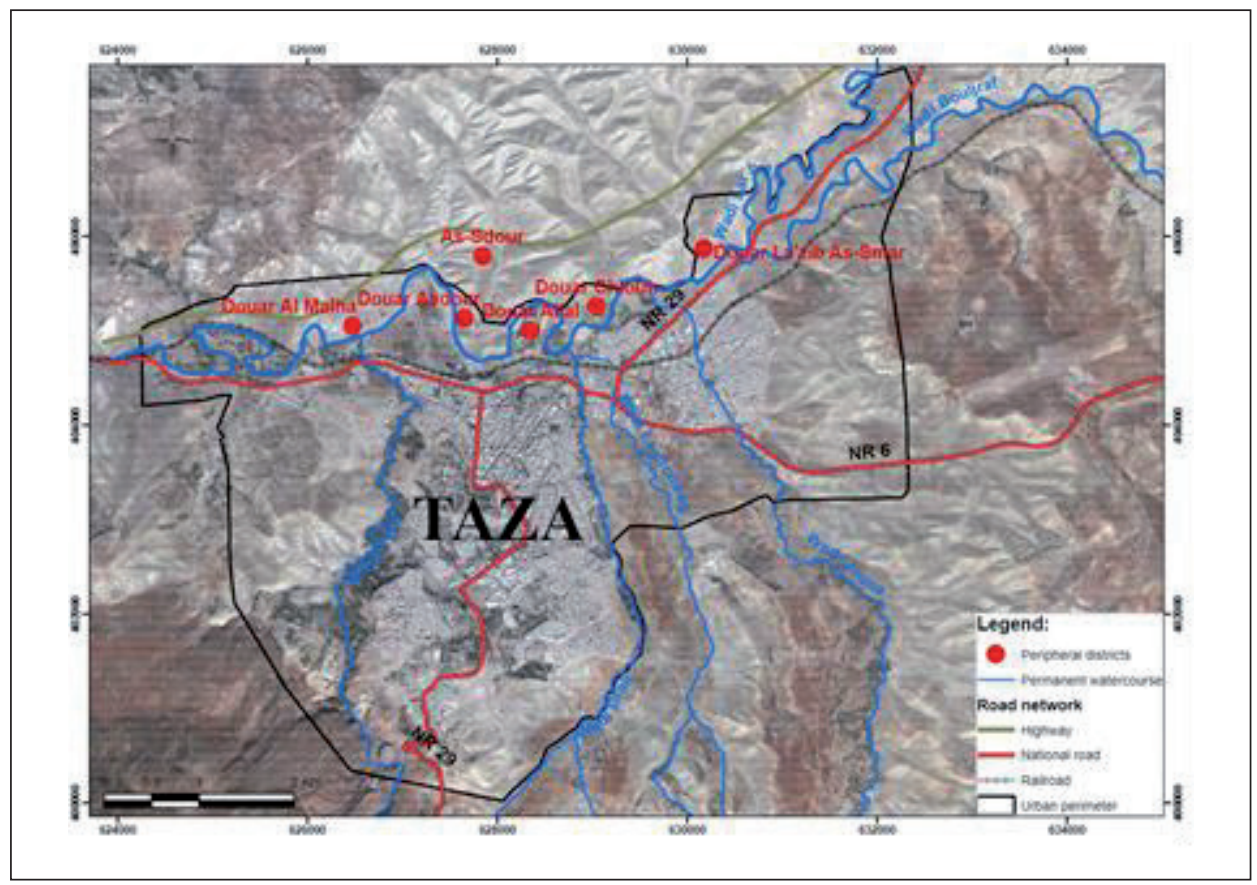

Figure 10. Location of non-regulatory neighborhoods in the northern peripheral zoneof Taza-city. Source: Google earth 2016 image / ANCF 2005 - Taza urban plan.

According to the testimonies collected in the field, the flood of September 27, 2000 is the most violent suffered by the population of these neighborhoods. The intense rains of this stormy episode (figure 4), were the source of serious floods of wadis Larbâa and Lahdar which dump their contributions in the upper course of the wadi Inaouène not far from the station of Bab Merzouka (located at $16 \mathrm{~km}$ from the city of Taza). According to the report of the DRH-Basin of Sebou (2000), the height of the flood, at Bab Chhoub station in the downstream section of wadi Lahdar, had reached $4.3 \mathrm{~m}$ around $17 \mathrm{~h} 30 \mathrm{~min}$ with a maximum flow rate of 550 $\mathrm{m}^{3}$ / S. As for the total volume of the flood, it was estimated at 4 million $\mathrm{m}^{3}$ (DRH-Sebou, 2000; Akdim et al., 2003; Taous et al., 2010). The violence of the flood was such that the Kasbat Béni Hitem hydrological station located downstream of wadi Larbâa was completely submerged over a height of $3 \mathrm{~m}$. At the Bab Merzouka hydrological station, located upstream of the wadi Inaouène, the flood has reached a maximum height of 7 $\mathrm{m}$, with a maximum flow of $1786 \mathrm{~m}^{3} / \mathrm{S}$ and a total estimated volume of 47.4 million $\mathrm{m}^{3}$ (DRH-Sebou, 2000; Akdim et al., 2003; Taous et al., 2010). This flood has caused a real catastrophe in the region. Several rural centers in the wadi Larbâa Valley have been affected (Tleta Traiba, Ain Boukella, Kasbat Beni Hitem). The outlying districts of the city of Taza, located downstream of wadi Larbâa, have been painfully affected (Douar 
Chlouh, Douar El Malha, Douar asdour) (DRH-Sebou, 2000; Akdim et al., 2003; Taous et al., 2010; Layan, 2013; Zyane, 2015).

The simulation of floods in Oued Larbâ, near these districts, shows that the width of wet sections can reach $300 \mathrm{~m}$ during a 50-year flood (Layan, 2013). The propagation of water could even reach the height $423.46 \mathrm{~m}$, corresponding to an overflow of $1.20 \mathrm{~m}$ in height, on human installations, such is the case of Douar El Melha on the right bank of Oued Larbâa (Layan, 2013). However, during a 100-year flood water covers the entire major bed. The overflow of waters corresponds to a catastrophic hydrological phase during which the width of the wet sections can exceed $350 \mathrm{~m}$ in certain sectors covering partially all of the Al Malha, Asdour and douar Allal districts and causing human loss and considerable material damage (Layan, 2013). Such was the case of the flood of September 27th, 2000, of which the flow was estimated at the level of the El Melha bridge at $1163 \mathrm{~m}^{3}$ / S (Agence Urbaine Taza, 2000; Agence Urbaine Taza, 2002; DRH-Sebou, 2000; Akdim et al., 2003; Taous et al., 2010; Layan, 2013).

This flood has been widely disastrous in terms of the affected population and damaged infrastructure. The official report records 6 deaths, in addition to hospitalizations. The material damage was significant affecting various sectors (crops, livestock, habitat, infrastructure, trade, etc.); they are officially estimated at more than 41 million dirhams (Province Taza, 2000; Taous et al., 2010). In the same way, the removal of the marly slopes of the basin as well as the erosion of the banks and the landslides make it possible, during this type of flood, to produce and to mobilize enormous quantities of sediments which affect the whole peripheral zones of Taza of the located downstream of wadi Larbâa (photo 2).

It is important to emphasize that certain anthropogenic elements increase the vulnerability of these environments in the face of the flooding risk. According to testimonies from the local population, the Taza landfill, located in a meander of Oued Larbâa upstream of Douar El Melha, is an essential factor which amplifies the overflows. The multiple wastes mobilized from the landfill, during the exceptional flood of September 27th, 2000, caused the obstruction of El Melha bridge located downstream. This blocked the flow, generating powerful overflowing floods in the neighboring districts. The bridges installed by the local population on the Oued Larbaa channel near the Al Malha and Asdour districts have been undersized and very poorly adapted, obstructing the circulation of water during floods; their obstruction is often aggravated by various wastes carried away by the flood. By their dam effect, these bridges cause an increase in the level of the flow at the time of floods (Akdim et al., 2003; Taous et al., 2010; Layan, 2013)). Embankments composed mainly of construction wastes constitute another form of anthropogenic impact favorable to flooding in this section of Oued Larbaa. They are easily erodable and are incorporated into the water flow, increasing the solid load and consequently the overflow and flooding conditions (Taous et al., 2010).

\section{CONCLUSION}

The close succession of exceptional rainfall events during the last decades constitutes really a source of risk threatening several areas of the northern provinces of Morocco. These rains, violent and concentrated over time, intervene directly in the mechanisms of erosion and floods. They are a determining factor that largely explains the intensity of erosive processes and the enormity of land loss in these environments. They also explain the deadly catastrophes of the "urban flooding" type that Morocco has experienced in recent years.

Besides the enumeration of these events and their harmful impacts on Rifan environments, we have also noted the responsibility of human societies as a factor which accelerates the degradation of environments and multiplies the damage caused by natural hazards. Successive societies in the region over the centuries bear, therefore, a great responsibility in the destabilization of the ecosystems and the modification of the components of the physical environment. This human pressure, to which various land use methods are linked, explains to a large extent, the intensity of environmental degradation. It has resulted, on most sides, in very spectacular agrarian conquests. The lack of land, the origins of which are generally historical or demographic, as well as human activities based mainly on cereals and livestock farming have largely contributed to a vast and varied alteration of natural vegetation and consequently to a serious damage of the 
environment. The current use of space reflects the extent of human influence and agrarian conquest. Land structures, shaken by various historical events, introduce varieties of occupation, almost are incompatible with the conditions of the physical environment. So indiscriminate clearing on steep slopes everywhere in the region and the practice of subsistence farming, that seeks to extract the maximum of food from the soil, it was enough to accelerate runoff and erosion processes. The overexploitation of cleared land, fueled by a rapidly growing population, explains the extension of crops to areas with steep slopes, resulting in the acceleration of runoff coefficients and erosion processes in this fragile environment.

Quantitative assessment of water erosion, using RUSLE model, in this Rifain region shows that average soil losses are well above tolerance levels, although they are close to national and regional ablation rates. Sediment production is therefore excessive, threatening soil capital and infrastructures downstream within the wadi Larbâa basin. Large sediment exports are mainly linked to the exceptional flows which characterize the autumn season when optimal runoff conditions are present (abundant and intense rains, bare and compacted soil, crust of beatings, etc.). These runoffs which generate networks of incisions on the abandoned clay soils are at the origin of spectacular degradations which evolve into badlands often marking the landscape for several years. However, the soil defense and restoration policy carried out by the technical development services remains contrary to the choice of the populations and the requirements of a subsistence economy in crisis. The achievements remain very weak and scattered over a few hectares in the region. During this time, the degradation of the Prerifan environments is accentuated and reaches very advanced stages; it requires immediate and large-scale interventions. These must be done in consultation with the local population; otherwise the difficulties of their implementation will be more and more difficult.

Likwise, the enormous human and material damage of the floods, during these last decades, also remind us of the extreme fragility of the urban fabric of the peripheries in the face of this new climatic trend. Uncontrolled urbanization, which developed during the 1980s, encroaching on the minor beds of watercourses, increased vulnerability to the flooding hazards. Several anarchic and unhealthy urban entities are built on the margins of regulation, in the absence of a rigorous policy on urban management. Thus, the public authorities must take the necessary measures to implement and apply the provisions and forecasts of urban planning documents. Similarly, any urban planning must pay particular attention to risk areas, particularly in peripheral zones, in order to avoid or at least reduce the damage caused by recurring flood events in the region. Also, considering the risk of flooding as an intrinsic component of this vulnerable territory can actively participate in changing the vision of planners and their partners as to how to take this phenomenon into account in the development process of the territorial construction. Simlarly, in oder to face these problems, it is of great importance for the concerned actors to rethink traditional systems of spatial planning. This requires the implementation of a bold strategy to address the past urban errors, in order to prevent the increase of human settlements in areas at risk. The recommended approach must include the evaluation, prevention, intervention and reconstruction phases in a process of continuous improvement that takes into account past experiences (Tribak et al., 2018).

Finally, it should be remembered that the causes of the dysfunctions imposed to cities and the problems they face, are also to be sought out, and in an urgent and priority way, beyond urban perimeters. The development of the poor and deprived countryside, which constitutes the hinterland of urban agglomerations, is more necessary than ever. These fragile and repulsive environments need sustainable development capable of fixing local populations and minimizing migratory movements. Similarly, the development of water resources, which is a determining factor in the stability of these countryside, remains a national priority that any rural development policy must take into account in order to face the serious consequences of any possible environmental crises. Similarly, watershed management and anti-erosion control require the integration of operations within the framework of a global rural development policy in the region, setting the objective of being compatible with physical and socio-economic conditions of this environment. This implies a renovation of the agrarian economy and a change in existing structures. This requires a modernization of the exploitation means and the imperative creation of other sources of income which can facilitate the reconversion of land and provide the local population with subsistence means. These measures would be likely 
to revalue the rural world, to meet certain expectations of local populations and consequently to reduce the magnitude of the emigration flows towards the surrounding cities.

\section{REFERENCES}

Abahrour, M. (2009). Contribution à l'évaluation quantitative de l'érosion hydrique dans le Prérif Oriental (Cas du bassin versant de l'Oued Teleta). (Thèse de doctorat en Géographie). FLSH Sais - Fès, 291 p. (Texte en Arabe)

Abahrour, M., Tribak, A. \& El Garouani, A. (2015). Dynamique du ruissellement et de l'érosion sur les terrains labourés du Prerif oriental: cas du bassin de l'Oued Tleta. In Acte du collqoue international: Eau et Climat: Regards croisés Nord/Sud (p. 99-106). Ublication FLSH sais-Fès, 52.

ANCF -Agence Nationale de la Conservation Foncière- (2005). Plan Urbain de la ville de Taza.

Agence Urbaine de Taza. (2000). Rapport portant sur les inondations survenues à Taza le 27 septembre 2000. Rapport interne, 6p.

Agence Urbaine de Taza. (2002).. Rapport analytique de crue de 22 Novembre 2002, 16p.

Akdim, B., Laaouane, M., Taous A. \& Obda, Kh. (2003). Risques hydrologiques dans la région de Taza, genèse, conséquences et problèmes d'aménagement. GéoMaghreb, 1, 47-60

Arari, KH., Tribak, A., Amhani, Z., Abahrour, M. \& El Ommal, M. (2019). Lérosion hydrique dans le prérif oriental: Cartographie et évaluation quantitative (Cas du bassin versant de l'oued Larbaâ-Maroc). In Actes du Colloque International la vulnérabilité des territoires face aux risques hydroclimatiques». Oujda 15 et 16 novembre 2019.

Argence, S. (2008). Prévisibilité de précipitations intenses en Méditerranée:impact des conditions initiales et application aux inondations d'Alger de novembre 2001. (Thèse doctorat: Physique de l'Atmosphère). Université Toulouse.

Ben Brahim,Y. (2006). Genèse météorologique des inondations de mars 2004 au NE du Maroc oriental. GéoMagreb 3, 47-54

Benchetrit, M. (1973). L'érosion actuelle et ses conséquences sur l'aménagement en Algérie. P. U. F.

Benchrifa, A. (1995). Processus de sédentarisation et risque de désertification: impact environnemental de l'évolution récente du nomadisme pastoral dans les hauts-plateaux du Maroc. In Série: Colloques et séminaires, 50, 79 - 97. Pub. FLSH. Rabat.

Bonn, F. (1998). La spatialisation des modèles d'érosion des sols à l'aide de la télédétection et des SIG: Possibilités, erreurs et limites. Sécheresse, 9 (3), 185-192.

Boudy, P. (1958). Economie forestière nord-africaine: Description forestière du Maroc. Tome 3. París: Ed. La rose.

Desplanques, H. (1969). Campagnes ombriennes: Contribution à l'étude des paysages ruraux en Italie centrale. Ed, Armand-Colin 1969

DRH Sebou, 2000. Crue du 27 Septembre 2000 dans la ville de Taza et régions. Rapport

El Aroussi, O., Mesrar, L., El Garouani., A., Lahrach, A., Benabidate, L., Akdim, B. \& Jabrane, R. (2011). Predicting the potential annual soil loss using the revised universal soil loss equation (RUSLE) in the Wadi el malleh catchment (prerif, morocco). Present Environment and Sustainable Development, 5 (2), 5 - 15.

El Garouani, A., Chen, H., Lewis, L.A., Tribak, A., Abahrour, M. (2009). Evaluation du bilan d'érosion et de dépôt des sols au pré-Rif (Maroc) en utilisant le modèle RUSLE, la télédétection et analyse spatiale. Revue Internationale de Géomatique, 19 (3), 303 - 317. https://doi.org/10.3166/geo.19.303-319

Gartet, A. (1994). Morphogénèse et hydrologie dans le bassin-versant de l'oued Lebène (Rif Méridional et Prérif Central et Oriental, Maroc). (Thèse de doctorat en géographie). Université d'Aix Marseille I, Institut de Géographie Aix-en-Provence.

Gomer, D. (1992). Écoulement et érosion dans des bassins versants à sols marneux sous climat semi-aride méditerranéen. Eschborn (Allemagne): GTZ-ANRH, 1992.

Grovel, R., 1996. La préservation des forêts du Rif centro-occidental: Un enjeu de développement de la montagne rifaine. Revue de Géographie Alpine, 4 (84), 75 - 94. https://doi.org/10.3406/rga.1996.3887

HCP -Haut Commissariat au Plan-, (1982-1994-2004-2014). Recensement général des populations et de l'habitat, Rabat.

HCP (Haut Commissariat au Plan), (2004). Aspects démographique et socio-économique de la région de Taza-Al Hoceima Taouante. 
HCP -Haut Commissariat au Plan-, (2005). Dynamique urbaine et développement rural au Maroc: Chapitre 1. Transition démographique - Transition urbaine.

Heusch, B. (1970). L'érosion dans le Prérif. Une étude quantitative de l'érosion hydrique dans les collines marneuses du Prérif occidental. Thèse. Ann, Rech, Forest, Maroc, 2, 9-176

Imeson, AC. \& Verstraten, JM., (1988). Rills on badlands slopes: a physico-chemically controlled phenomenan. CATENA. Supplement 12, 139-150.

Janati Idrisi, A., Mazoz, E. \& Smihi, W. (2017). Circulation atmosphérique et ressource en eau dans le cadre du changement climatique (cas du bassin de Sebou, Maroc). Publication FLSH, Sais-Fès, 3-29.

Jennan, L. (1990). Evolution récente des systèmes socio-économiques et différentiation spatiale du Moyen Atlas. In Actes du colloque, le Maroc: espace et société. Passau 1989, 73-84

Kerbout, M. (1990). Les mutations des campagnes du Moyen Atlas oriental: Le cas de Beni Yazgha et des Marmoucha. Actes du colloque, le Maroc: espace et société. Passau 1989, 49 - 62.

Layan, B. ( 2013). Détermination des crues de projet, modélisation hydraulique et gestion du risque d'inondation dans le bassin versant de l'oued Larbaâ. cas de la ville de Taza (Maroc). (Thèse Doctorat, géologie).

Leblanc, D. (1979). Etude géologique du Rif externe oriental au Nord de Taza (Maroc). Notes et Mémoires. Rabat: Service Géologique Marocain, $\mathrm{n}^{\circ} 281$.

Lelandais, F. \& Fabre G. (1996). Plan d'aménagement anti-érosif du bassin-versant de l'oued Ouergha (Maroc), Risques d'érosion et systèmes d'information géographique. Bull Réseau Erosion 16, 439-443.

Lewis, L., Chen, H. \& El Garouani, A. (2007). Modeling soil erosion and deposition utilizing remote sensing and GIS in the Tlata river basin, Morocco. European Geosciences Union 2007, Geophysical Research Abstracts, Vol. 9.

López-Bermúdez, F. (2003). Evaluación de la erosión hídrica en las áreas receptoras de los embalses de la Cuenca del Segura. Aplicación de la USLE. In: F. López-Bermúdez y J.B. Thornes (Eds.), Estudios sobre Geomorfología del Sur de España (93-99). Murcia: Universidad de Murcia y University of Bristol.

Lyrintzis, G. \& Papanastasis, V. (1995). Human activities and their impact on land degradation. Psilorites mountain in Grete: A historical perspective. Land degradation and rehabilitation, 6, 79-93. https://doi.org/10.1002/ldr.3400060203

MADREF (Ministère de l'Agriculture, du Développement rural et des Eaux et Forêts), (1994). Plan national d'aménagement des bassins-versants. Rapport de synthèse. Rabat: MADREF. Retrieved from http://www.eauxetforets.gov.ma/pabv. htm\#haut.

Mathieu, L. (1977). La géomorphologie et la géologie quaternaire comme bases fondamentales pour une juste définition et une cartographie rapide des sols et des milieux. Application dans la province de Taza (Maroc) et dans la cuvette d'Andoppa (Madagascar). (Thèse Doc ing F.S.A.). Gembloux, Belgique.

Maurer, G. (1990). Facteurs physiques et aménagement dans la montagne rifaine. Extr. Rev. Fac des lettres. Tetouan. 4 ème année: 4, 93-101.

Maurer, G. (1991). Les dynamiques agraires dans les montagnes rifaines et telliennes au Maghreb. Bull.Assoc. Géogr. Franç., 4, 267-279. Paris. https://doi.org/10.3406/bagf.1991.1584

Maurer, G. (1996). L'homme et les montagnes atlasiques au Maghreb. Ann. Géog., 587, 47-72. https://doi.org/10.3406/ geo.1996.20726

Merzouk, A., Fenjiro, I. \& Laouina, A. (1996). Cartographie de l'évolution des formes d'érosion dans le Rif Occidental (Maroc): étude multidate utilisant un SIG-Bassin versant. Bull Réseau Érosion,16, 444-56.

Morscell, J. \& Fox, D. (2004). Une méthode de la cartographie du risque érosif: application aux collines de Terrefort laugarais M@ppemonde, 76 (2004.4). Retrieved from http://mappemonde.mgm.fr/mm4/articles/art04404.html.

Morsli, B., Mazour, M., Mededjel, N., Hamoudi, A. \& Roose, E. (2004) Influence de l'utilisation des terres sur les risques de ruissellement et d'érosion sur les versants semi-arides du nord ouest de l'Algérie. Sécheresse, 15 (2), 96-104.

Morsli. B., Habi, M., Mazour, M., Hamoudi, A. \& Halitim, A. (2012). Erosion et ruissellement en montagnes méditerranéennes d'Algérie du Nord: analyse des facteurs conditionnels sous pluies naturelles et artificielles Rev. Mar. Sci. Agron. Vét., 1, 33-40

Naimi, M., Tayaa, M. \& Ouzizi, S. (2004). Cartographie des formes d'érosion dans le bassin-versant de Nakhla (Rif occidental, Maroc). Rev, Sécheresse 16, 79-82.

Neboit, G.R. (1983). L'homme et l'érosion ASS des publications de la Fac.des Lettres et sci. Humaines de Clermont-ferrand 2 Nouvelle série fasicule 17. 
Province de Taza. (2000). Les inondations survenues le 27 septembre 2000. Rapport interne 22 p.

Rango, A. \& Arnoldus, H.M.J. (1987). Aménagement des bassins versants. Cahiers techniques de la FAO.

Renard, K.G., Foster, G.R., Weesies, G.A., McCool, D.K. \& Yoder, D.C.(1997). Predicting Soil Erosion by Water: A Guide to Conservation Planning with the Revised Universal Soil Loss Equation (RUSLE). Agricultural Handbook, $\mathrm{n}^{\circ}$ 703, Washington, D.C.

Romero, R., Doswell III, C. A. \& Ramis, C. (2000). Mesoscale Numerical Study of Two Cases of Long-Lived Quasi-Stationary Convective Systems over Eastern Spain. Mon. Wea. Rev., 128 (11), 3731-3751. https://doi.org/10.1175/1520-0493(2001)129<3731:MNSOTC>2.0.CO;2

Roose, E. (1996). Méthodes de mesure des états de surface du sol, de la rugosité et des autres caractéristiques qui peuvent aider au diagnostic de terrain des risques de ruissellement et d'érosion, en particulier sur les versants cultivés de montagne. Réseau Erosion Bulletin, 16, 87-97.

Royaume du Maroc. (1992). Schéma Directeur d'Aménagement et d'Urbanisme -Taza. Ministère de l'Intérieur.

Royaume du Maroc. (2015). Schéma Directeur d'Aménagement et d'Urbanisme -Taza. Rapport de diagnostique - analyse et évaluation prospective. Ministère de l'Habitat de l'Urbanisme et d'Aménagement du Territoire, Agence Urbaine Taza.

Sabir, M., Roose, E., Ouagga, T., Bensalah, N. \& Dore, L. (2007). Utilisations des terres et risques de ruissellement et d'érosion dans les montagnes au Maroc. Actes des JSIRAUF. Hanoi, 6-9 novembre 2007.

Sadiki, A., Bouhlassa, S., Aujjar, J., Faleh, A. \& Macaire, J.(2004). Utilisation d'un SIG pour l'évaluation et la cartographie des risques d'érosion par l'équation universelle des pertes en sols dans le Rif oriental (Maroc): Cas du bassin de l'Oued Boussouab. Bulletin de l'Institut Scientifique de Rabat, 26, 69-79.

Sauvage, C. (2019). Prévision couplée océan-atmosphère des épisodes méditerranéens: Impact d’une meilleure prise en compte des débits des fleuves et de l'état de mer. (Thèse doctorat Sciences de l'Univers, de l'Environnement et de l'Espace). Université toulouse.

Taous, A., Obda, Kh., Tribak, A., Laouane, M., Akdim, B., Marques Furdada, M. \& Julia, R. (2010). Cartographie et zonage de l'aléa d'inondation à Taza (Maroc). Application de la méthode géomorphologique intégrée. Géomaghreb, 6, 1-19.

Tribak, A. (2000). L'érosion hydrique en moyenne montagne du Prérif oriental (Maroc). Etude des agents et des processus d'érosion dans une zone de marnes tertiaires. (Thèse Doctorat d'Etat).

Tribak, A. (2002). Contraintes du milieu et fragilité d'un espace montagnard marocain: Les montagnes du Prérif oriental. Annales de géographie, 625, 227-245. Paris: Armand colin. https://doi.org/10.3406/geo.2002.1655

Tribak, A. (2006). Impacts des phénomènes pluviométriques exceptionnels sur les milieux montagnards marocains: cas du Prerif oriental. In Actes du XIX colloque de l'association internationale de climatologie «les risques liés au temps et au climat », 526-531. Epernay France, septembre 2006.

Tribak, A., El Garouani, A. \& Abahrour, M. (2009). Évaluation quantitative de l'érosion hydrique sur les terrains marneux du PréRif oriental (Maroc): Cas du sous-bassin de l'oued Tlata. Sécheresse, 20 (4), 333-337. https://doi.org/10.1684/ sec.2009.0205

Tribak, A., El Garouani, A. \& Abahrour, M. (2012). Hydrous erosion in the catchment area of the wadi larbaa (Rif mountains, Morocco): Agents, processes and modeling. Present Environment and Sustainable Development, 6 (2), 7 - 20.

Tribak, A., Arari, K., Abahrour, M., El Garouani, A. \& Amhani, Z. (2015). Quantitative assessment of the hydric erosion and the deposition in a marly catchment of the eastern Rif (case of wadi Tarmast - Morocco. Annals of Valahia University of Targoviste. Geographical Series Tome 15/2015, 2, 101-24.

Tribak, A., Abahrour, M., El Garouani, A., Arari, Kh. \& Amhani, Z. (2017). Evaluation quantitative de l'érosion hydrique dans un environnement montagnard méditerranéen: cas de quelques bassins marneux du Prérif oriental (Maroc). In Eau et climat en Afrique du Nord et au Moyen-Orient (101-112). Publication UMR IDDES-Rouen.

Tribak, A. \& El Amrani, H. (2018). Urban occupancy of areas with flood risk and territorial dynamics: The case of the great Nador agglomerations (Morocco). Revista de Estudios Andaluces, 36, 54-71. http://dx.doi.org/10.12795/rea.2018.i36

Tribak, A., El Amrani, H., Abahrour, M., Zyane, F. Z., Azagouagh, k., En-Nasry, E.H., Benriah, N. \& El Yagoubi Roudani, S. (2019). Occupation des sites à risques en zones périurbaines: Causes, modalités et conséquences: Cas des villes de Fès et Taza (Maroc). Geo-Eco-Trop., 43, 2, 249-258.

Wengler, L. (1993). Cultures préhistoriques et formations quaternaires du Maroc oriental: relation entre comportements et paléo-environnements au Paléolithiques moyen. (Thèse d'état). Bordeaux I.

Wischmeier, W.H. (1976). Use and misuse of the universal soil loss equation. Journal of Soil and Water Conservation, 31 (1), 5-9. 
Wischmeier, W.H. \& Smith, D.D. (1978). Predicting rainfall erosion losses - a guide for conservation planning. U.S. Department of Agriculture, Agriculture Handbook, Washington, D.C.: 1-537.

Zyane, FZ. (2015). Occupation des zones à risques et dynamique territoriale dans les zones périphériques de la ville de Taza. Mémoire Master Géographie ‘ LAGEA, FLSH Sais -Fès.

\section{WEBS}

https://earthexplorer.usgs.gov - LandSat $8^{\text {th }}$, October 2017

Image Google earth 2016 /

http://www1.wetter3.de/archiv_gfs_dt.html)

http://mappemonde.mgm.fr/mm4/articles/art04404.html. 